

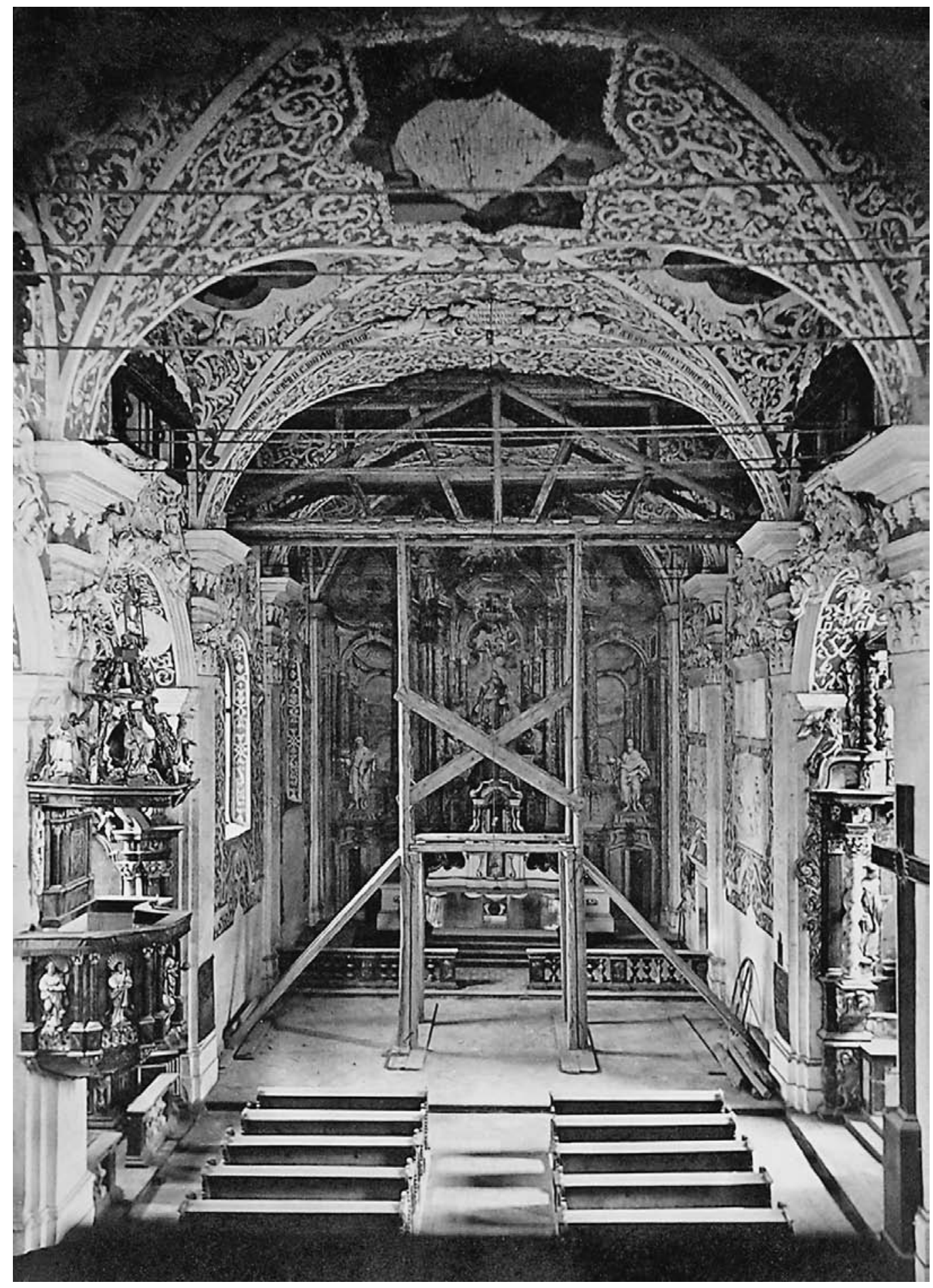

Sl. 1. Crkva svete Katarine nakon oštecenja u potresu (fot. IVAn Standl, 1880.)

Fig. 1 The Earthquake-damaged Church of St. Catherine (Photo by IVAn Standl, 1880) 
Dragan Damjanović

SVEUČILIŠTE U ZAGREBU

FILOZOFSKI FAKULTET

ODSJEK ZA POVIJEST UMJETNOST

HR - 10000 ZAGREB, I. LUČICA 3

dragan.damjanovic@gmail.com

IZVORNI ZNANSTVENI ČLANAK

https://doi.org/10.31522/p.28.2(60).5

UDK 72.035 (497.5 ZAGREB) "18"

TEHNIČKE ZNANOSTI / ARHITEKTURA I URBANIZAM

2.01.04. - POVIJEST I TEORIJA ARHITEKTURE I ZAŠTITA GRADITELJSKOG NASLIJEĐA

HUMANISTIČKE ZNANOSTI / POVIJEST UMJETNOSTI

6.09.01. - POVIJEST I TEORIJA LIKOVNIH UMJETNOSTI, ARHITEKTURE, URBANIZMA I VIZUALNIH KOMUNIKACIJA

ČLANAK PRIMLJEN / PRIHVACEN: 2. 10. 2020. / 16. 12. 2020.
UNIVERSITY OF ZAGREB

FACULTY OF HUMANITIES AND SOCIAL SCIENCES

DEPARTMENT OF ART HISTORY

CROATIA - 10000 ZAGREB, I. LUČICA 3

dragan.damjanovic@gmail.com

Original SCIENTIFIC PAPER

https://doi.org/10.31522/p.28.2(60).5

UDC 72.035 (497.5 ZAGREB) "18"

TeChNical SCIEnces / ARChitecture And URban Planning

2.01.04. - HISTORY AND THEORY OF ARCHITECTURE and Preservation of the Built Heritage

HUMANITIES / ART HISTORY

6.09.01. - History ANd Theory of Fine Arts, ARCHitecture, Urban Planning and Visual Communication

Article Received / AcCepted: 2. 10. 2020. / 16. 12. 2020.

\title{
ORGANIZACIJA OBNOVE ZAGREBA NAKON POTRESA 1880. GODINE
}

\section{ORGANIZATION OF REPAIR AND RECONSTRUCTION WORKS IN ZAGREB AFTER THE 1880 EARTHQUAKE}

\begin{abstract}
Članak govori o organizaciji obnove Zagreba nakon potresa 9. 11. 1880. godine. Usredotočuje se na način na koji su tijela tadašnje hrvatske Zemaljske vlade, zagrebačkoga Gradskog poglavarstva i drugi organi vlasti, obnavljali tijekom studenoga i prosinca 1880. javne građevine te kontrolirali obnovu privatnih zgrada. Završni se dio teksta usredotočuje na način na koji su osigurana potrebna sredstva za obnovu grada.
\end{abstract}

\author{
FINANCIRANJE OBNOVE \\ JAVNA ARHITEKTURA \\ POTRES 1880. GODINE \\ SANACIJA GRADA NAKON POTRESA \\ ZAGREB
}

\author{
FUNDING REPAIR AND RECONSTRUCTION \\ PUBLIC ARCHITECTURE \\ 1880 EARTHQUAKE \\ POST-EARTHQUAKE CITY REHABILITATION \\ ZAGREB
}

This paper focuses on the organization of repair and reconstruction works after a devastating earthquake hit Zagreb in 1880. It specifically looks at how the bodies of the Croatian Provincial Government, the Zagreb City Government and other authorities were managing the rehabilitation and reconstruction of public buildings and controlling the renovation of private houses. It also examines the way in which the necessary funds were provided. 


\section{UVOD}

\section{INTRODUCTION}

otres 9. 11. 1880. godine jedna je od najvecih prirodnih katastrofa koja je tijekom povijesti pogodila Zagreb. ${ }^{1} \mathrm{U}$ arhitekturi i urbanom razvitku ovoga grada potres je odigrao iznimno značajnu ulogu.

Cilj je ovoga teksta na prvome mjestu prikazati način na koji su hrvatske vlasti organizirale sanaciju građevina $u$ Zagrebu neposredno nakon toga potresa, u studenomu i prosincu 1880., s kojim su se financijskim i drugim ograničenjima suočavale te tko je konkretno bio angažiran na izvedbi i kontroli radova. Tekst se temelji na dokumentaciji središnjih organa vlasti Trojedne Kraljevine (Predsjedništva i Unutrašnjega odjela Zemaljske vlade) i vijestima iz onodobnih zagrebačkih novina, provladinih „Narodnih novina” i „Agramer Zeitunga”, te opozicijskog „Obzora”. U tekstu ograničene duljine nije bilo moguce, dakako, dotaknuti se svih važnih pitanja koja su se javila pri sanaciji grada, niti je obuhvaceno cijelo stradalo područje sjeverozapadne Hrvatske, vec samo tadašnji teritorij grada Zagreba ${ }^{2}$

Tekst je popracen fotografijama oštecenih građevina (najvecim dijelom javnih i sakralnih zgrada) koje su izradili onodobni istaknuti zagrebački fotografi Ivan Standl i Hermann Fickert, te ilustracijama preuzetima iz ilustriranih časopisa i monografija objavljenih vezano za potres od 9. 11. 1880. godine (SI. 2.).

\section{HRVATSKA ZEMALJSKA VLADA, KRAJIŠKE I VOJNE VLASTI TE ORGANIZACIJA SANACIJE ZAGREBA NAKON POTRESA}

\section{Croatian Provincial Government, MILITARY FRONTIER AND OTHER \\ MILITARY AUTHORITIES AND \\ ORGANIZATION OF POST-EARTHQUAKE \\ REHABILITATION AND RECONSTRUCTION OF ZAGREB}

Kako je dobro poznato, s obzirom na okolnost da je u posljednjih nekoliko mjeseci nakon ovogodišnjega potresa o tome višestruko pisano, potres koji je pogodio Zagreb 9. studenoga 1880. oko sedam i trideset ujutro bio je procijenjene jačine od 6,1-6,3 prema Richterovoj skali. Radilo se, dakle, o daleko jačemu potresu od ovogodišnjega pa ne čudi da su gotovo sve građevine $u$ gradu bile $u$ većoj ili manjoj mjeri oštecene. Neposredno nakon potresa stanovnici Zagreba našli su se u iznimno nezavidnom polożaju. Potres se dogodio početkom studenoga, magle su tih dana veci dio noci i prijepodneva prekrivale grad, a hladni dani već su započeli, što je predstavljalo golem problem jer su brojne peći u potresu bile srušene. Kako je plin morao biti isključen zbog oštecenja Plinare, velik broj stanova nije imao ni rasvjetu. Bogatije građanstvo, osobito žene i djeca, vec je stoga na dan potresa počelo napuštati grad, a kako su se naknadni udari ponavljali tjednima nakon 9. studenoga, tako se i sve veci broj stanovnika selio iz Zagreba.

Vlada onodobne Trojedne Kraljevine Hrvatske, Slavonije i Dalmacije, na čelu s banom Ladislavom Pejačevicem i unionistički (promađarski) nastrojenom Narodnom strankom, reagirala je promptno, usprkos iznimno teškim okolnostima. lako je nakon prvoga potresnog udara isti dan uslijedilo još niz slabijih potresa, već u prijepodnevnim satima 9. 11 . 1880. državne su službe nastavile s radom. Ban je u 11.30 sati najprije obavijestio telegramom cara i kralja Franju Josipa I. (koji se tada, čini se, nalazio u Budimpešti) o velikom stradanju Zagreba i okolice ${ }^{3}$, a odmah sljedeci dan izdana je i prva naredba načelnicima, predstojnicima i ravnateljima javnih institucija, koja se odnosila na potrebu sanacije javnih građevina. Potres se dogodio u kasnu jesen, kada se uskoro mogla očekivati ili kiša ili snijeg, pa je bilo potrebno hitno intervenirati kako bi se spriječilo daljnje propadanje oštecenih javnih građevina. U banovoj nared-

1 Ovaj je rad financirala Hrvatska zaklada za znanost projektom IP-2018-01-9364 Umjetnost i drżava u Hrvatskoj od prosvjetiteljstva do danas.

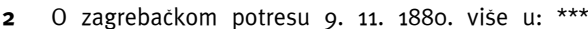
1880.b; *** 1880.c; TORBAR, 1882.; HANTKEN VON PRUDNIK, 1882.; WÄHNER, 1883.; SZABO, 1971: 131-133; BUNTAK, 1980: 25-34; LADOVIĆ, PREMERL, 1981.; KAMPUŠ, KARAMAN, 1994: 215; BUNTAK, 1996: 774; HOLJEVAC, 2012: 346-347; DAMJANOVIC, 2013: 72-75; Vadas, 2013: 66-88 


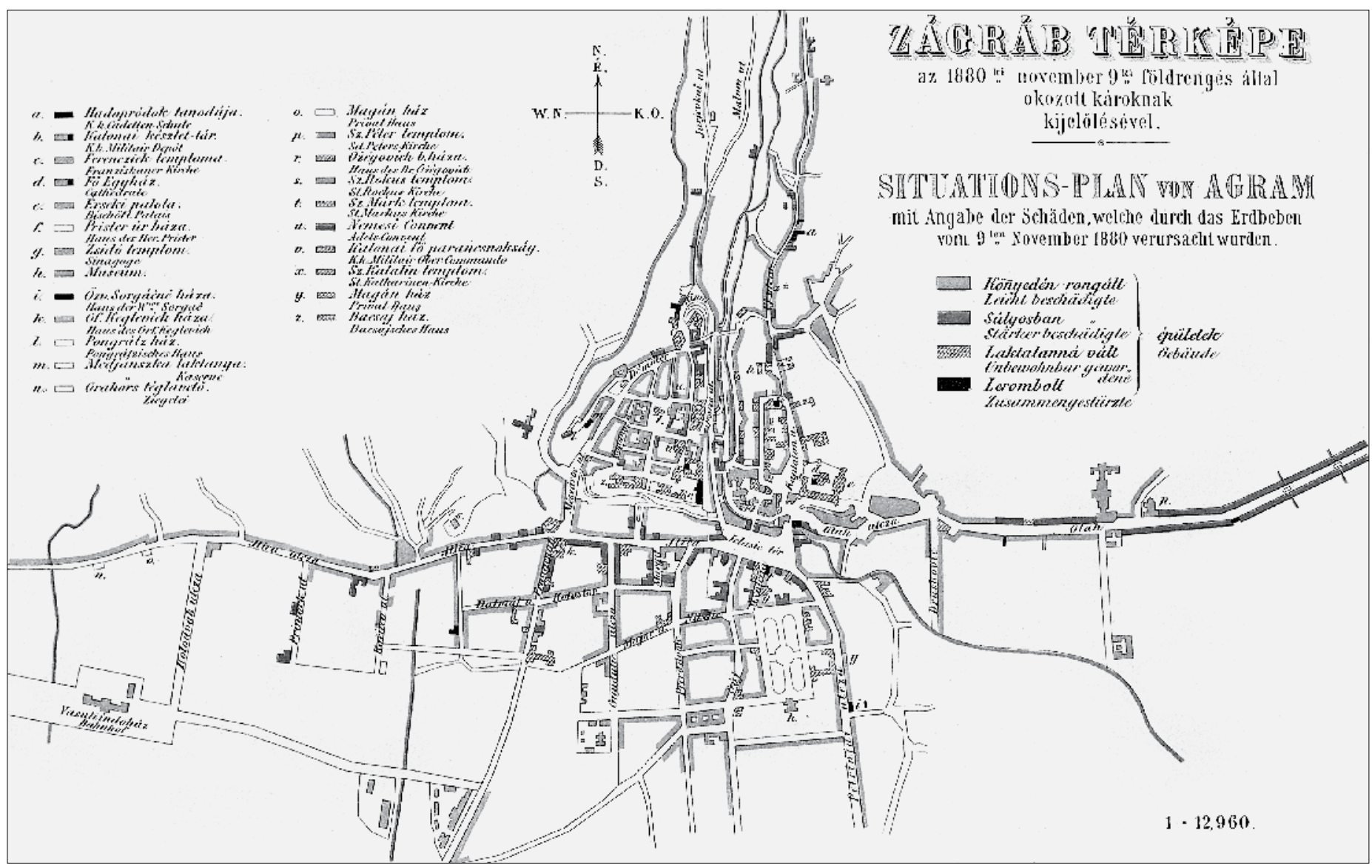

bi istaknuto je stoga čelnicima javnih institucija da trebaju voditi računa o državnim nekretninama kao da je riječ o njihovim vlastitim građevinama i da trebaju odrediti „da se sve one prostorije, koje isti pomocju u mjestu nalazeciih se meštarah, civilnih inžinirah vladinih i podž.[upanijskih] tehnikah ili inih strukovnjakah i radnikah popraviti ili očistiti uzmognu - odmah poprave i očiste". Pod tim je podrazumijevao odstranjivanje żbuke koja je visjela sa zidova i stropova, uklanjanje popucalih zidova i dimnjaka, popravak krovova crijepom ili provizorno drvom da padaline ne uništavaju unutrašnjost zgrada, podupiranje onih dijelova zgrada koji prijete urušavanjem, zatvaranje zgrada i prostorija koje privremeno nisu za upotrebu te prenošenje predmeta iz njih u druge prostorije ili zgrade koje se mogu koristiti, kao i poduzimanje svih drugih nužnih popravaka i uređenja. ${ }^{4}$

3 HR-HDA-78, Predsjedništvo Zemaljske vlade [dalje PRZV], kut. 121, sv. 6-2483, 1880., 2483, ban Ladislav Pejačevic kralju Franji Josipu I., Zagreb, 9. 11. 1880.

4 HR-HDA-79, Unutrašnji odsjek Zemaljske vlade [dalje UOZV], kut. 396, sv. 10-8, 25047-1880., dok. 25407 , Ban Ladislav Pejacevic, Naredba svim predstojnikom, načelnikom, ravnateljem oblastih, sudovah, učilištah, zavodah, itd. Kraljevine Hrvatske i Slavonije, Zagreb, 10. 11. 1880 .
Isti je dan Građevni odsjek Unutarnjeg odjela Zemaljske vlade - i inače zadužen za gradnju i održavanje javnih građevina koje su bile u okviru nadležnosti hrvatskih autonomnih vlasti unutar ugarskog dijela Monarhije, a koji je tada vodio poduzetni Juraj Augustin - napravio prve korake u raspoređivanju svojega osoblja na radove na sanaciji javnih zgrada. Posla je bilo mnogo, s obzirom na okolnost da su sve zgrade u vlasništvu Vlade bile oštecene. Državni su inženjeri bili podijeljeni u osam skupina. O obnovi banske zgrade (banskih dvora), regnikolarne zgrade (zgrada smještena uz banske dvore $\mathrm{i}$ povezana $\mathrm{s}$ njima), nekadašnje Fericeve zgrade (Markov trg 3), palače Županije (danas dio Sabora) i Narodnog kazališta (danas Skupština Grada Zagreba) starali su se nadinženjer Kamilo Bedeković i inženjerski pristav Ivan Juračić, s time da su radove na županijskoj zgradi trebali nadzirati u dogovoru s inženjerom Zagrebačke županije Josipom Čabrianom. Zgradu Dvorane (Narodni dom), sudbenu zgradu (vjerojatno se misli na zgradu suda na Zrinjevcu) i žensku kaznionicu (tada na Savskoj ulici) obnavljao je inženjer Srećko (Felix) Jacomini, a Zemaljsku ludnicu (Umobolnicu u Stenjevcu) inženjer Ivan Bartušek s projek-
SL. 2. Karta oštecenja Zgrada u Zagrebu u potresu 9.11. 1880.

FIG. 2 MAP OF DAMAGED BUILDINGS IN ZAGREB AFTER THE EARTHQUAKE ON 9 NOV, 1880

SL. 3. UNUTRAŠNJOST KRALJEVSKOGA PLEMIĆKOG KONVIKTA NAKON POTRESA 9. 11. 1880. (FOT. IVAN STANDL, 1880.) FIG. 3 INTERIOR OF THE ROYAL NOBLE DORMITORY AFTER THE EARTHQUAKE ON 9 NOV, 1880 (PHOTO BY IVAN STANDL, 1880)

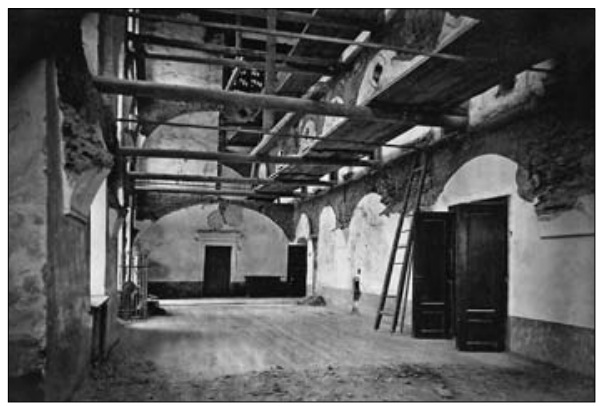



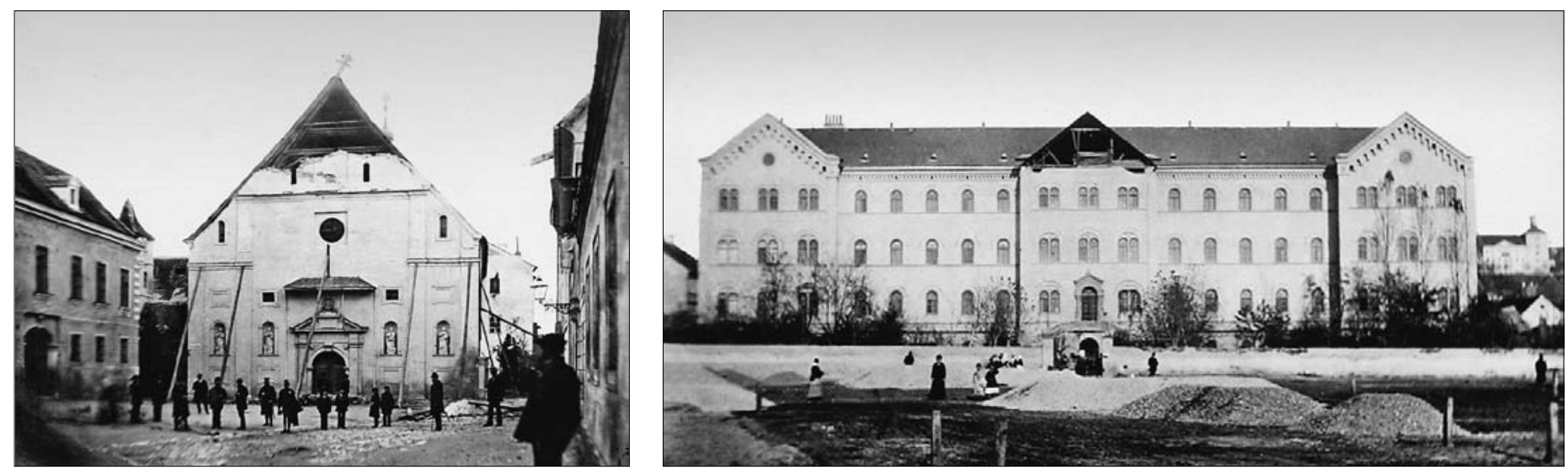

SL. 4. UČVRŠCiVANJE OŠTECENOG PROČELJA CRKVE SVETE KATARINE NAKON POTRESA (FOT. HERMANN FICKERT, 1880.) FIG. 4 BRACING THE EARTHQUAKE-DAMAGED FACADE OF THE Church of St. Catherine (Photo by Hermann Fickert, 1880)

SL. 5. ZgradA TVORNICE DUHANA (DANAS SVEUČILIŠTA U ZAGREBU) NAKON POTRESA (FOT. HERMANN FICKERT 1880.)

FIG. 5 TOBACCO FACTORY BUILDING (TODAY THE UNIVERSITY OF ZAGREB) AFTER THE EARTHQUAKE (PHOTO BY HERMANN FICKERT, 1880)

SL. 6. GLAVNo PRoČELJE ZGRADE GENERALKomANDE I CRKVE SVETE KATARINE NAKON OŠTECENJA U POTRESU, PREMA GRAFICI J. SMUTNYJA

FIG. 6 MAIN FACADE OF THE GENERAL COMMAND BUILDING AND THE CHURCH OF ST. CATHERINE DAMAGED IN THE

EARTHQUAKE, ACCORDING TO THE GRAPHIC BY J. SMUTNY tantom građevine Kunom Waidmannom. Obnovu Muzeja, zgrade JAZU, Gajeve kuce (u kojoj se nalazila Gruntovnica, Ćirilometodska 4) i Plemickog konvikta (Sl. 3.) (danas Gimnazija Tituša Brezovačkog) vodio je inženjer Slavoljub Schmidt; Gimnazije i Sveučilišta (koji su se nalazili u zgradi na Katarinskom trgu) te crkve sv. Katarine (Sl. 4.) i Tvornice duhana (Sl. 5.; današnja zgrada Sveučilišta) inženjer Adolf Felbinger; Računarskog ureda i Kegleviceve kuce (tada palača Narodnih novina, istočni ugao Ilice i Frankopanske) inženjerski pristav Žiga Egersdorfer; zgradâ srednjih učilišta, škola i preparandija inženjerski vježbenik Mato Hanžeković, a Kemičkog laboratorija (tada na južnom kraju Nove Vesi) inženjerski pristav Franjo vitez Ernst.

Popravak zgrada nadzirao je Odbor za isplatu prešnih gradjevnih popravakah na potresom oštecenih zemaljskih i županijskih sgradah, koji je djelovao od 13. 11. 1880. do konca srpnja 1881. godine. ${ }^{6}$ Cilj je bio da se na svim javnim zgradama (u koje su tada spadale i crkve te župni dvorovi) poprave, odnosno da se na njima provedu „samo najnuždnije preservativne mjere, ... da se uzčuvaju od posvemašne propasti i to predbiežno na trošak uredovne naklade, negledeć na okolnosti tko ce te troš-

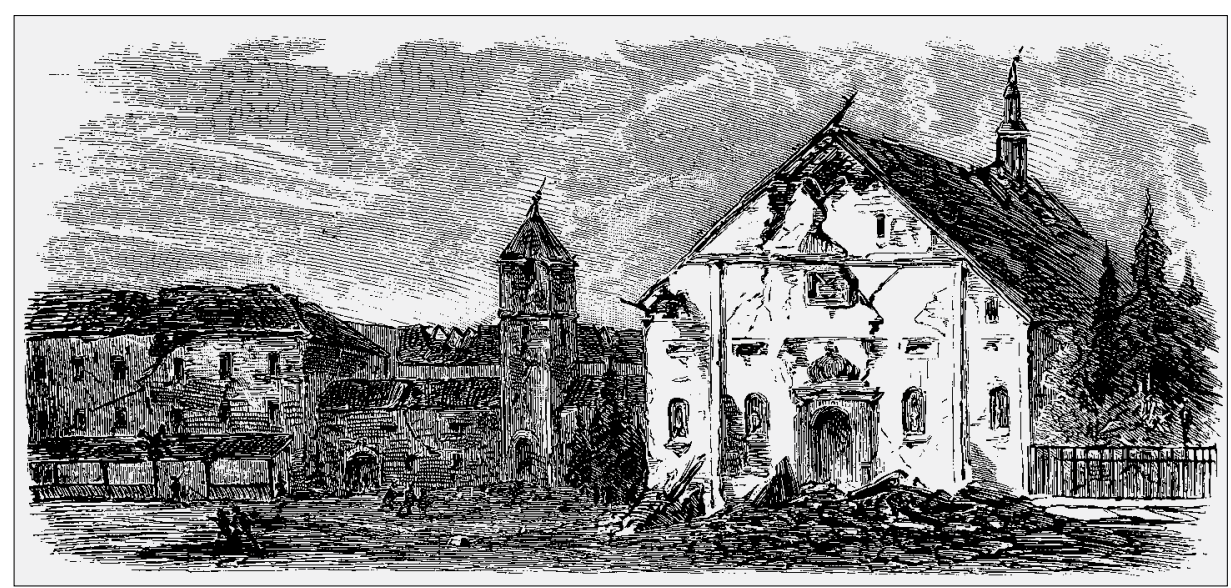

kove konačno namiriti, ter ostavljajujuć uzpostavu rečenih sgradah u prijašnje stanje kasnijoj razpravi". 7 Gotovo sve su te građevine bile u dovoljnoj mjeri sanirane da su se mogle ponovno početi koristiti u prosincu 1880., osim dviju koje su bile najjače oštecene: „jedino crkva sv. Katarine i sgrada pl. Konvikta nisu se mogle u privremeno uporabljivo stanje staviti, pa je crkva sv. Katarine posve za uporabu nesposobna bez znatnoga pregradjenja, a sgrada pl. Konvikta je u južnom i iztočnom krilu takodjer nesposobna za uporabu bez znatnoga uredjenja i pregradjenja". ${ }^{8}$

Ovi najnužniji popravci javnih zgrada stajali su oko 46.000 forinti koji su pribavljeni izvan-

5 HR-HDA-79, UOZV, kut. 396, sv. 10-8, 25047-1880., dok. 25228-1880., Okružnica predstojnika Gradjevnog odsjeka Jurja Augustina, Zagreb, 10. 11. 1880.; ${ }^{\star \star \star} 1880.0: 4$ 6 HR-HDA-79, UOZV, kut. 684, sv. 10-8, 219-1881., dok. 21608-1881., Ignjat Sieber Računarskom uredu Zemaljske vlade u Zagrebu, Zagreb, 30. 8.1881.

7 HR-HDA-78, PRZV, kut. 156, sv. 6-1, 1881., dok 294 1881., PRZV Odjelu za bogoštovlje i nastavu [dalje ZVBiN] Zagreb, 29. 1. 1881.

8 HR-HDA-79, UOZV, kut. 684, sv. 10-8, 219-1881., dok. 5158-1881., Gradjevni odsjek UOZV-u, Zagreb, 24. 2. 1881.

9 HR-HDA-79, UOZV, kut. 684, sv. 10-8, 219-1881., dok. 5263-1881., Zapisnik o konferenciji Zemalj. Vlade, držanoj dne 26. travnja 1881. pod predsjedanjem bana Ladislava Pejacevica

10 Isto, Juraj Augustin, „Izkaz troškovah za izvesti se imajuce popravke u potresom oštecenih javnih sgradah u Zagrebu", Zagreb, veljača 1881.

$11 U$ taj su iznos uključeni radovi izvedeni 1880. godine. 12 HR-HDA-79, UOZV, kut. 684, sv. 10-8, 219-1881., dok. 5263-1881., Zapisnik o konferenciji Zemalj. Vlade, drżanoj dne 26. travnja 1881. pod predsjedanjem bana Ladislava Pejačevica

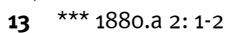

14 HANTKEn Von PRudNik, 1882: 52-53

$15 \mathrm{U}$ to su vrijeme $\mathrm{u}$ Vojnograđevnom ravnateljstvu ra dili i satnici Dragutin Janušek i Franjo Mally, natporučnik Franjo Schlegerhofer te oficijal Benedik Müller. Za pretpostaviti je kako su oni surađivali na obnovi vojnih zgrada s osobljem Građevnog odsjeka Vojne Krajine kojemu je tada predstojnik bio nadmjernik Dragutin Uhlig, a osim njega unutar Odsjeka su bili zaposleni nadmjernik Franjo Poppl, mjernici Gabrijel Dienel, Franjo Nemetz, Martin Lassbacher, te mjernicki asistenti Ivan Meyer, Ferdinand Bitzan, Dragutin Legit, barun Alfred Benko, Stjepan Buckl, Franjo Czihak i Josip Dvorżak. [VuJASINOVIĆ, 2003-2004: 418] 

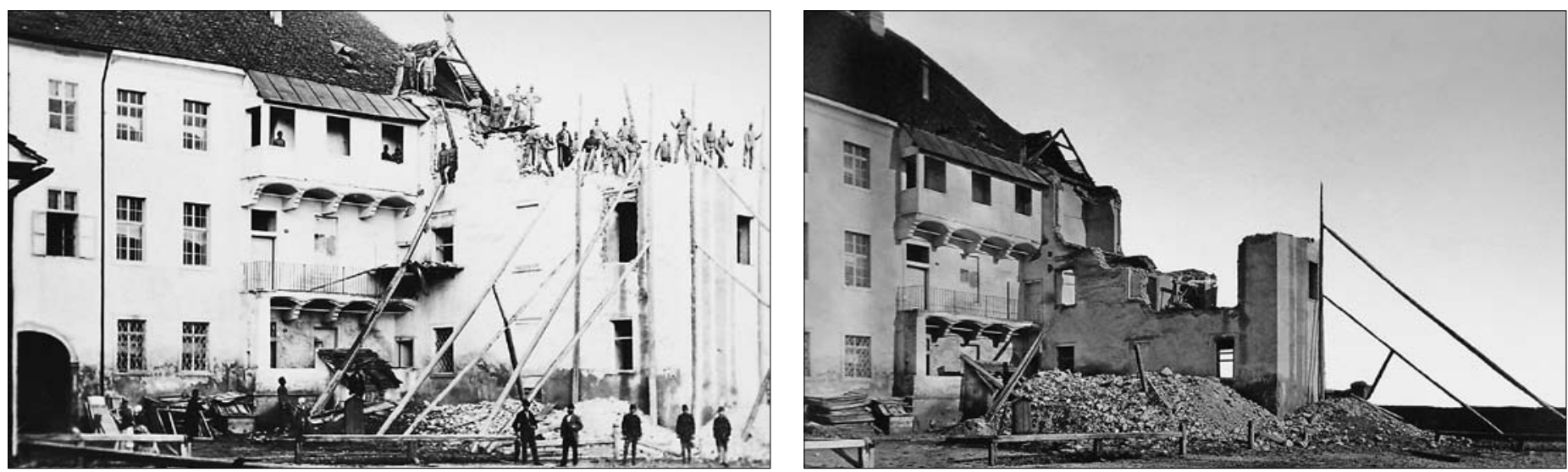

rednim izdacima proračuna uglavnom iz raznih zemaljskih zaklada, kojima je poslije trebalo vratiti novac. ${ }^{9}$ Svim su ovim građevinama, međutim, predstojali daljnji veći popravci tijekom 1881. godine, kojih je ukupna vrijednost bila najprije procjenjivana na 60.000 forinti, od čega se polovica odnosila na dvije spomenute najoštećenije zgrade - popravak crkve svete Katarine procjenjivao se na 20.000 forinti, a plemickog konvikta na 10.000 forinti. ${ }^{10}$ Naposljetku se ispostavilo da ukupna vrijednost radova na raznim javnim zgradama stradalim u potresu, u Zagrebu i okolici iznosi oko 160.000 forinti ${ }^{11}$ koje je vlada odlučila pokriti zajmom. ${ }^{12}$

Sustav javnih institucija u Zagrebu bio je tada vrlo složen, pa je tako i povijest organizacije obnove grada nakon potresa 1880 . vrlo složena. Osim Zemaljske vlade Trojedne Kraljevine Hrvatske, Slavonije i Dalmacije, u to je vrijeme u Zagrebu stolovala još jedna vlada - za Vojnu krajinu, odnosno, kako se službeno nazivala, Carsko kraljevsko glavno zapovjedništvo u Zagrebu kao krajiška zemaljska upravna oblast, tada na čelu s generalom barunom Franjom Filipovicem. Konačno, stanovitu ulogu u obnovi imala su i tijela Zagrebačke županije te ministarstava $\mathrm{i}$ institucija koja su imala sjedišta u Budimpešti i Beču, odnosno koja su bila zajednička za ugarsku polovinu Monarhije ili za cijelu državu.

Zajednička Ugarsko-hrvatska vlada vodila je tako popravak zgrade Financijskog ravnateljstva i Glavne državne blagajne. ${ }^{13}$ Vojnokrajiška pak vlada u suradnji s Vojnograđevnim ravnateljstvom u Zagrebu provodila je popravke vojnih zgrada. Od zgrada pod upravom vojnokrajiške vlade najjače je stradalo njezino sjedište na Jezuitskom trgu (nekadašnji Isusovački samostan, danas zgrada Galerije Klovicevi dvori; Sl. 6.). Ured u kojem je inače radio zapovjednik Filipovic bio je jako oštecen. Morao se, nadalje, ukloniti toranj iznad ulaza u zapadno krilo zgrade, kao i dio južnog krila (prema današnjem platou Gradec) koje se urušilo (SI. 7. i 8.). Velika je oštecenja pretrpjela i Kadetska škola na Novoj Vesi (Sl. 9.), a stanovita i Vojna bolnica u Vlaškoj, te vojarne (SI. 10.). Dokumentaciju o popravcima zgrada pod upravom Generalkomande nije se uspjelo pronaci, no iz posrednih izvora doznaje se kako je radove na obnovi vodio Antun pl. Hirsch, ravnatelj Vojnograđevnog ravnateljstva u Zagrebu ${ }^{14}$, zasigurno uz pomoc drugih zaposlenika ove institucije. ${ }^{15}$
SL. 7. UKLANJANJE JUŽNOG KRILA ZGRADE GENERALKOMANDE NA PLATOU GRADECA NAKON POTRESA (FOT. HERMANN FICKERT, 1880.)

FIG. 7 REMOVING THE SOUTH WING OF THE GENERAL COMMAND BUILDING ON THE GRADEC PLATEAU AFTER THE EARTHQUAKE (PHOTO BY HERMANN FICKERT, 1880)

SL. 8. JUŻNO KRILO ZGRADE GENERALKOMANDE NA PLATOU GRADECA NAKON ŠTO JE VECI DIO UKLONJEN (FOT. IVAN STANDL, 1880.)

FIG. 8 SOUTH WING OF THE GENERAL COMMAND BUILDING ON THE GRADEC PLATEAU AFTER ITS MAJOR PART HAD BEEN REMOVED (PHOTO BY IVAN STANDL, 1880)

SL. 9. ŠKOLA VOJNIČKIH PITOMACA (KADETSKA ŠKOLA) NAKON POTRESA (FOT. HERMANN FICKERT, 1880.) FIG. 9 SCHOOL OF MILITARY CADETS (CADET SCHOOL) AFTER THE EARTHQUAKE (PHOTO BY HERMANN FICKERT, 1880)

SL. 10. Radovi na MedianskyjeVoj Vojarni u Visoko ULICI NAKON POTRESA (FOT. HERMANN FICKERT, 1880.) FIG. 10 WORKS ON MEDIANSKY'S BARRACKS

IN VISOKA ST, AFTER THE EARTHQUAKE (PHOTO BY HERMANN FICKERT, 1880)
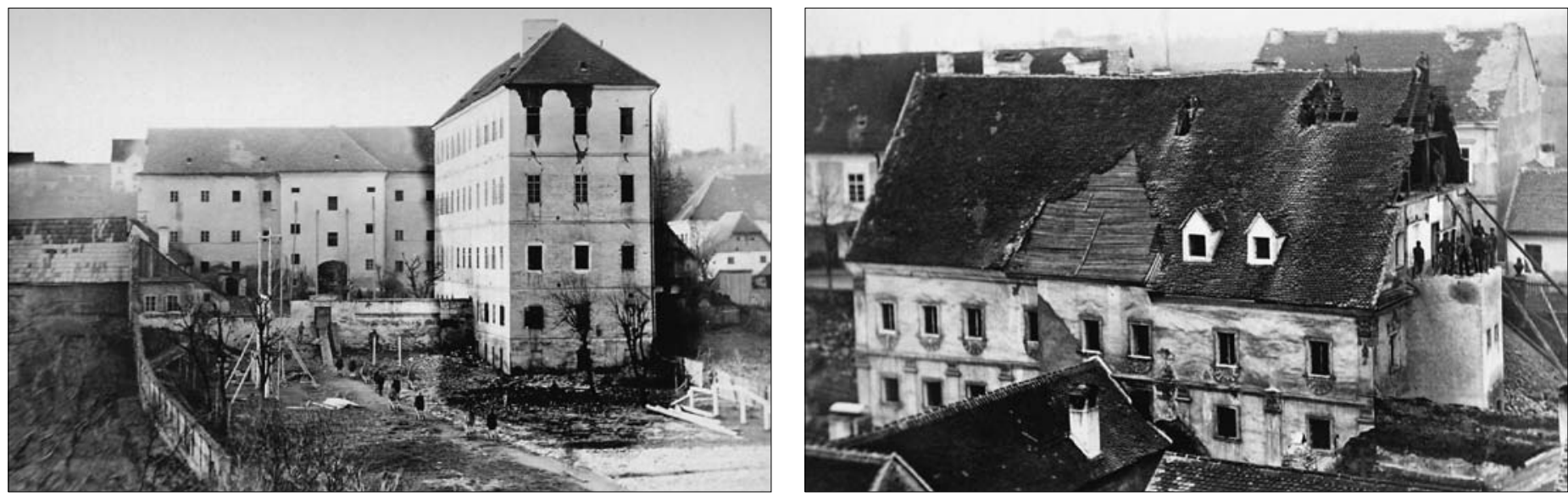


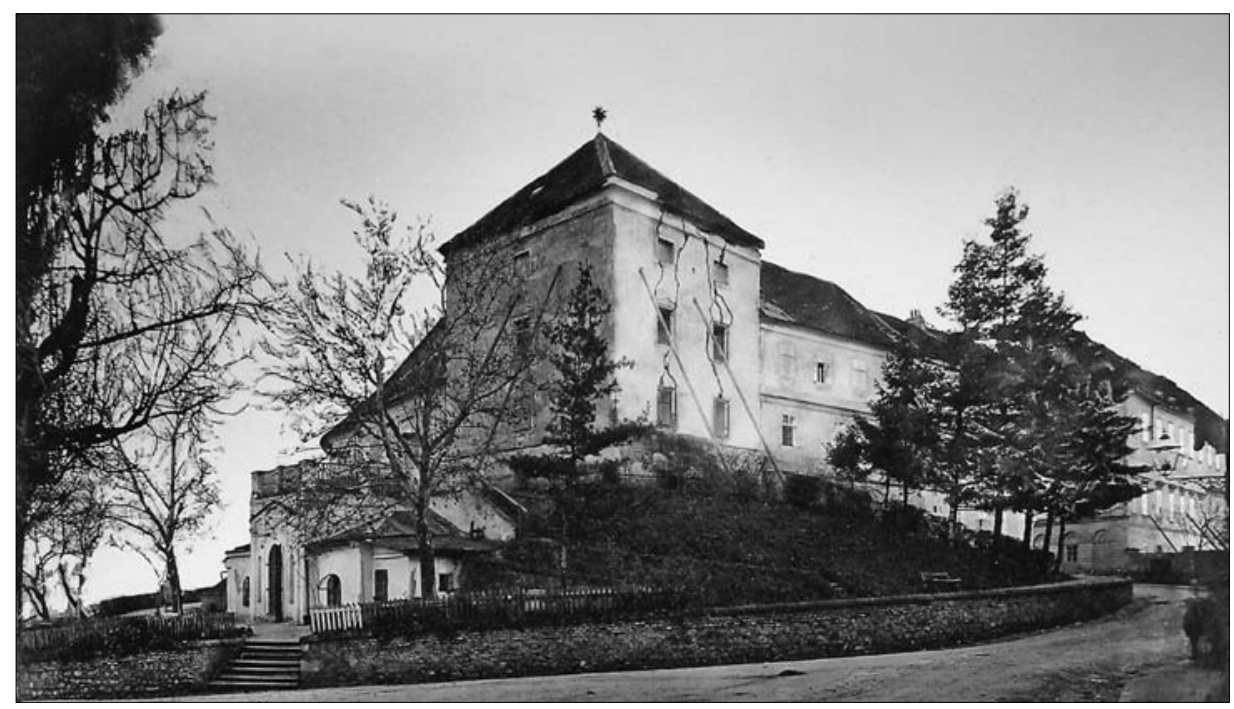

SL. 11. POPOV TORANJ NAKON POTRESA. U POZADINI SE VIDI PALAČA ERDÖDY-DRAŠKOVIĆ, DANAS DRŽAVNI ARHIV U ZAGREBU, PODUPRTIH ZIDOVA ZBOG OŠTECENJA U POTRESU (FOT. IVAN STANDL, 1880.).

FIG. 11 PRIEST'S TOWER (POPOV TORANI) AFTER THE EARTHQUAKE. IN THE BACKGROUND: ERDÖDY-DRAŚKOVIC PALACE, TOdAY THE StATE ARCHIVE IN ZAGREB. THE EARTHQUAKE DAMAGED-WALLS ARE BRACED (PHOTO BY IVAN STANDL, 1880)
Vojnokrajiške vlasti organizirale su komisijske preglede svojih zgrada u suradnji s vlastima Trojedne Kraljevine ${ }^{16}$, što se zasigurno treba pripisati okolnosti da se pripremalo pripojenje Vojne krajine Hrvatskoj (zaključeno 1. 8. 1881.) pa se nastojalo buduce korisnike ovih zgrada uputiti u njihovo stanje.

lako je sustav javnih službi u Zagrebu bio vrlo složen, zahvaljujući čemu je velik broj građevinskih inženjera bio zaposlen u raznim institucijama, te iako je u gradu djelovao čitav niz raznih arhitekata, graditelja i drugih majstora, u cjelini gledajuci - Zagreb u tom trenutku nije raspolagao s dovoljno stručnoga osoblja niti s dovoljno radnika da se saniraju sve nastale štete. Ban je stoga četiri dana nakon potresa, 13. 11. 1880., donio odredbu o suspendiranju dijela postojecih odredbi vezanih za izdavanje dozvola za rad u Hrvatskoj kako bi što veći broj stručnjaka privukao u Zagreb i okolne podżupanije. Buduci da na područjima oštecenima u potresu „Nisu po postojecih propisih ovlašteni zidarski, tesarski, klesarski meštri i graditelji kadri, da potrebite popravke na sgradah prije nastavše zime izvedu. Da se obcinstvu omoguci i olahkoti potrebite popravke što skorije izvesti, od potrebe je, da se stranim zanatlijam i radnikom dozvola podieli, u što vecem broju radnje izvesti, ter $u$ tu svrhu postojece propise, u tom smislu razširiti”. Odredbom je na prvome mjestu bilo utvrđeno da su „Strani zidarski, tesarski i klesarski meštri i graditelji austrougar. Monarkije ovlašteni [...] do daljnje odredbe u području gore spomenutih podžupanijah i gradovah, poslove izvršivati uz poglavarstveno opredjeljene, ili još niže, ali nipošto više ciene, ako se izkazati mogne da su u austro-ugarskoj Monarkiji, gdjegod za samostalno izvršivanje obrta svoga ovlašteni”. Radnici su pak mogli doci iz bilo kojeg područja. Bilo je dovoljno samo da se prijave zagrebackom Gradskom poglavarstvu ili drugim nadležnim organima vlasti. ${ }^{17}$
Kako bi što veći broj stručnjaka sudjelovao u obnovi grada, bila je nužna pomoć i viših tijela vlasti u Hrvatskoj i Monarhiji. U pomoc $\mathrm{Hr}$ vatskoj pritekle su tako vrlo brzo nakon potresa središnje institucije iz Beča, na prvome mjestu Ministarstvo rata iz Beča, jedno od rijetkih ministarstava nadležnih za cijelo područje Monarhije nakon Austro-ugarske nagodbe 1867 . Uz blagoslov vladara u Zagreb su stoga već 12 . 11. stigle dvije satnije - Inženjerska i Pionirska. ${ }^{18}$ Inženjerska je satnija na čelu sa zapovjednikom Antunom Merkleinom, nadporučnikom Dragutinom Müllerom vitezom Sturmthalom i poručnikom Franjom Reschom $^{19}$ - radila na sanaciji zgrada privatnih kucevlasnika i Zemaljske vlade, dok je Pionirska, na čelu sa zapovjednikom Maierom, radila na zgradama Vojnoga erara, osobito središnje zgrade Generalkomande ${ }^{20}$, te Kadetske škole u Novoj Vesi. ${ }^{21}$

\section{GRADSKO POGLAVARSTVO I SANACIJA ZAGREBA NAKON POTRESA}

\section{CitY GOVERNMENT AND POST-EARTHQUAKE REHABILITATION AND RECONSTRUCTION OF ZAGREB}

Gradsko je poglavarstvo, dakako uz tijela Zemaljske vlade, pa čak i više od njih, s obzirom na svoje nadležnosti, odigralo ključnu ulogu u organizaciji sanacije grada.

Poput bana i Zemaljske vlade, i gradske su vlasti nakon potresa doista promptno reagirale. Najvažnije je bilo raščistiti ulice kako bi promet mogao neometano teci. S obzirom na onodobne tehničke mogućnosti, kao i velika oštećenja, fascinantno je da su u roku od 24 sata ulice bile toliko čiste „da bi čovjek, sudeći po vanjskomu licu grada, a nezaviriv u nutarnjost kuca, gdje se pokazuju učinci potresa, jedva vjerovao, da je zlo bilo tako veliko".22

Isticalo se da kada bi kakav stranac „...vidio one čile i liepe kuce, gdjekoju iz vana ni malo oštećenu, čiste ulice bez svakog znaka ruševinah. Mislio bi, da su grozne viesti samo špekulativno zavaravanje svieta, da je ružna šala, koju su novinari sbijali - ali kad bi ga tko god od Zagrebčanah uveo u nutarnjost ma koje kuce, počam od kardinalova i banova

16 HR-HDA-79, UOZV, kut. 396, sv. X-8, 25047-1880., dokument 27247-1880., UOZV Generalkomandi u Zagrebu, Zagreb, 10. 12. 1880 .

17 HR-HDA-79, UOZV, kut. 396, sv. 10-8, 25047-1880., dok. 25289-1880., Naredba bana Ladislava Pejacevica, Zagreb, 13. 11. 1880 .

$18 * * * 188$ o.h: $1-2$

19 HR-HDA-78, PRZV, kut. 121, sv. 6-2483, 1880., 2894 , Gradsko poglavarstvo Zagreb [dalje GPZ] PRZV-u, Zagreb, 17. 12. 1880.

$20 \star \star \star$ 1880.x: $2-3$ 
dvora do malih novoveških kolibah, osvjedočio bi se o strašnih posliedicah katastrofe od 9. studenoga". ${ }^{23}$

Na sam dan potresa Gradsko je poglavarstvo, nadalje, podijelilo grad na 12 kotara i u svaki je bio poslan jedan ili dva inženjera s predstavnikom Gradskog zastupstva kako bi se ustanovila točna oštecenja zgrada. ${ }^{24} \mathrm{U}$ komisijama su bili sljedeći predstavnici: 1 . Gustavu Pongratzu i inženjeru Žigi Egersdorferu dodijeljene su na pregled ulice: Gospodska (danas Ćirilometodska), Kamenita, Opatička, Pivarska (danas Basaričekova), Samostanska (?), Vijećnička (danas Kuševiceva), Županijska (danas Ulica 29. 10. 1918.), Trg svete Katarine i ostale njima susjedne manje ulice (Sl. 11.); 2. Inženjeru Franji vitezu Ernstu i Aleksandru Secu dodijeljene su Demetrova, Jurjevska, Kapucinska, Kazališna (danas dio Demetrove), Markova, Mletačka, Sjemenišna (danas Vranyczanyjeva) i Visoka ulica, te Kipni (danas Ilirski) i Markov trg i okolne ulice; 3. Gradskom zastupniku Milanu Stankovicu i inženjeru Marcelu pl. Kuševicu dodijeljene su Mesnička, Bregovita (danas Tomiceva) i Duga (danas Radiceva) ulica, zatim Ilica od Jelačićeva trga do Frankopanske, te Trg bana Jelačića s okolnim ulicama; 4. Inženjeru Adolfu Felbingeru dodijeljene su Berislaviceva, Gajeva, Kukoviceva (danas Hebrangova), Nikoliceva (danas Teslina) i Preradoviceva ulica, te $s$ njima povezane bočne ulice; 4. Inženjeru Dragutinu Uhligu i gradskom zastupniku Antunu Eisenhutu dodijeljene su Ulica Marije Valerije (danas Praška), Petrinjska i Sudnička (danas Amruševa) ulica, te Zrinjski trg i ostale njima susjedne manje ulice; 5. Inženjeru Gabrijelu (Gabri) Dienelu i gradskom zastupniku Milanu Nosanu dodijeljene su Dalmatinska, Frankopanska, Gunduliceva, Marovska (danas Masarykova) i Samostanska (danas Varšavska) ulica te s njima povezane pobočne uličice; 6 . Inženjerima Camillu Cordonu i Rikardu (Richardu) pl. Rüscheru te gradskom dnevničaru Marku Gerovcu, dodijeljene su Ciglana, Ilica od Frankopanske do Kolodvorske ceste (danas Ulica Republike Austrije), Kačiceva, Meduliceva i ostale bočne ulice; 7. Inženjerima Alfredu Benku i Franji (Franzu) Nemecu (Nemetzu) te gradskom dnevničaru Janku Pisačiću dodijeljene su Bakačeva ulica, Nova Ves, Kaptolski trg i s njima povezane pobočne uličice; 8 . In-

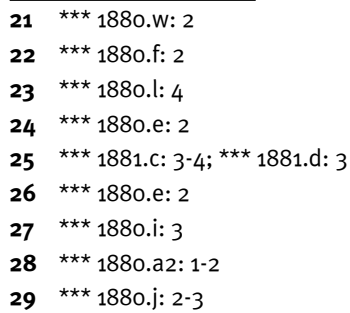

ženjeru Carlu pl. Berteleu i potkapetanu Franji Teodorovicu dodijeljene su Kożarska ulica, Krvavi most, Opatovina, Potok, Skalinska i ostale pobočne ulice; 9. Inženjeru Slavoljubu Schmidtu (Šmitu) i gradskom zastupniku Ferdi Šaju dodijeljene su Draškoviceva, Ribnjak, Vlaška i Nadbiskupski (danas Langov) trg s okolnim ulicama; 10. Inženjeru Vilimu Sorgneru i gradskom zastupniku Josipu Franku dodijeljena je Savska cesta; 11. Inženjeru Antunu Seemülleru i gradskom pisaru Miroslavu Mečečeviću dodijeljena je Ilica od Kolodvorske ceste do kraja grada na zapadnoj strani, Radnički dol, Sv. Rok i ostale njima susjedne manje ulice. Važnije su zgrade pregledala posebna povjerenstva. Za crkve, javne zavode i tvornice bilo je tako zaduženo povjerenstvo koje su činili gradski vijecnik, poznati književnik August Šenoa i gradski mjernik Rupert Melkus, dok su gradski vodovod pregledali gradski vijecnik Adolf Hudovski i gradski inženjer Milan Lenuci. Konačno, gradski zastupnik Vatroslav Egersdorfer i ravnatelj plinare Karlo Munder pregledali su Plinaru (SI. 12.). Na pregledane zgrade lijepljene su „poglavarstvene obznane”. Ako su bile upotrebljive, stavljana je obavijest „ova kuca pogledana je povjerenstveno i pronadjena u povoljnom stanju”, a na one koje nisu bile upotrebljive stajala je obavijest: „U ovoj kuci zabranjuje se boravljenje do dalnje odredbe." ${ }^{25}$ Pojedine kuce morale su biti deložirane, s obzirom na stanje u kojem su se nalazile ${ }^{26}$, a Grad se pobrinuo da deložirane obitelji budu privremeno smještene u stanovima koje je imao u svojemu vlasništvu. ${ }^{27}$

Pregled zgrada bio je tek prvi korak koji se odnosio na površno ustanovljene štete. $U$ mnogo slučajeva pokazalo se da nije dovoljan jedan pregled, a pojedine zgrade bile su pregledane i šest puta kako bi se ustanovili razmjeri šteta. ${ }^{28}$ Dakako, precizno ustanoviti koliko je neka zgrada bila opasna za korištenje nije bilo moguce u to vrijeme. Za one koji su ostali u oštećenim kucama preporučivao se stoga test za koji se vjerovalo da donekle pokazuje koliko je kuća u lošemu stanju. $\mathrm{Na}$ pukotinu na zidu trebalo je staviti traku papira i pričvrstiti je na suprotnim stranama pukotine. Ako nakon 6-12 sati papir pukne, zgrada se trebala smatrati opasnom za stanovanje, a to je opasnija bila što je papir prije pukao. ${ }^{29}$

Kako bi se pomoglo kucevlasnicima kojih su zgrade bile oštecene i kako bi se spriječile špekulacije koje su se javile neposredno nakon potresa, Gradsko je poglavarstvo već dan nakon potresa donijelo odredbu o ograničenju cijena građevinskog materijala i građevinskih radova. Na ove su uvjete pristali gotovo svi graditelji Zagreba: F. Cerilia, Janko Grahor, Vjekoslav Heinzel, Janko Jambrišak, Oton Jokuš, Ferdinand Kondrat, Francesco (Franjo) Matiassi, Ernest Mühlbauer, Ivan

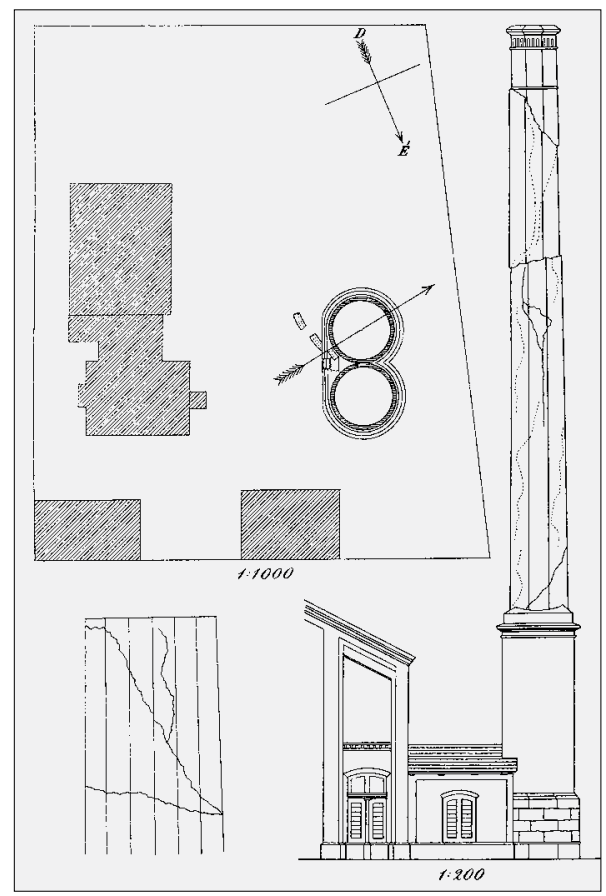

SL. 12. Plinara u Zagrebu nakon oštećenja U POTRESU 1880.

FIG. 12 GASWORKS IN ZAGREB, DAMAGED IN 1880 EARTHQUAKE 

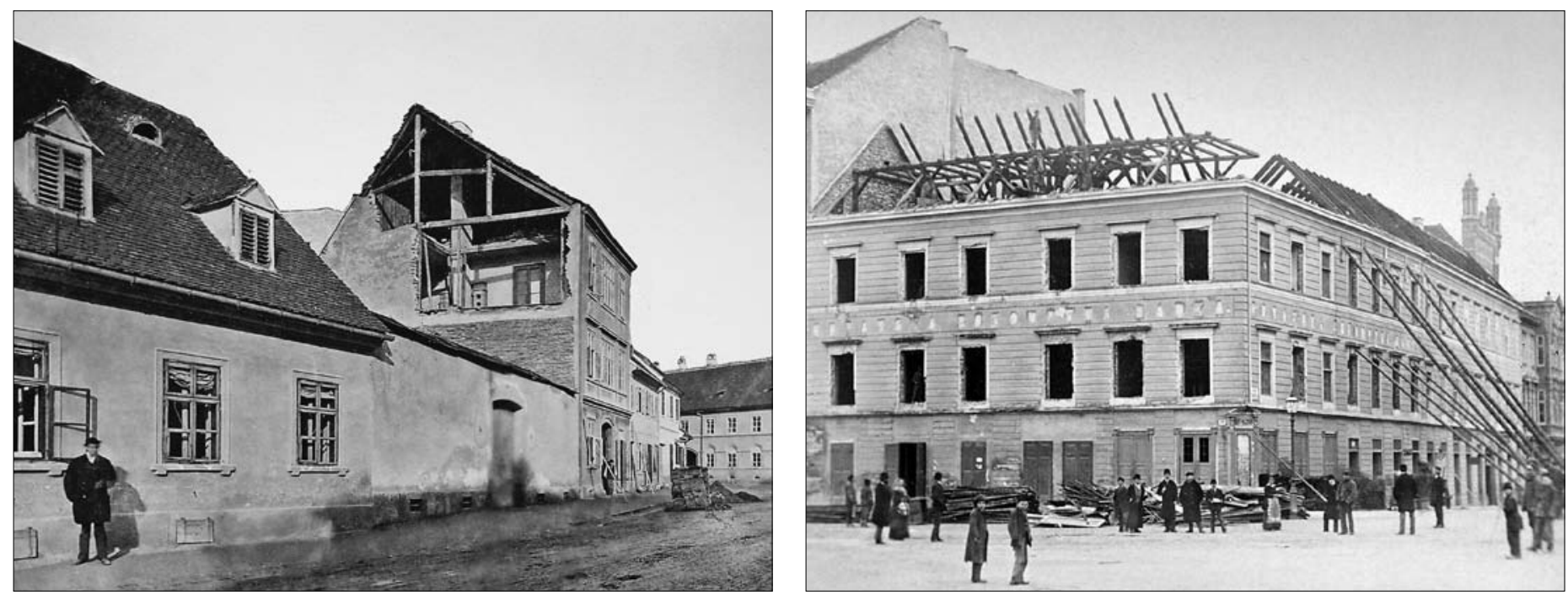

SL. 13. MAROVSKA (DANAS MASARYKOVA) ULICA NAKON POTRESA 9. 11. 1880. ZGRADA KOJOJ SE URUŠIO ZID STOJI I DANAS U MASARYKOVOJ 6 (FOT. IVAN STANDL, 1880.).

FIG. 13 MAROVSKA (TODAY MASARYKOVA) STREET AFTER THE EARTHQUAKE ON 9 NOV, 1880. THE BUILDING WITH A DEMOLISHED WALL STILL EXISTS AT 6, MASARYKOVA St. (РHOTO BY IVAN STANDL, 1880)

Sl. 14. UkLanjanje kuce Emanuela Pristera (TRG BANA JELAČICA / PRAŠKA ULICA) NAKON POTRESA 1880.

Fig. 14 Removing Emanuel PrISTER'S house dAMAGED IN the 1880 earthquake (on BAN JelaĆıĆ SQ. / PRAŠKa St.)
Plochberger, Ivan Šnuparek (Schnuparek), Ferdo Steyskal (Stejskal) i Gjuro Šviglin. ${ }^{30}$ Dakako, usprkos tim odredbama cijene su divljale jer su špekulanti iskoristili situaciju za brzu zaradu. ${ }^{31}$

Nakon što se neposredno nakon potresa $u$ glavnim crtama dobila slika o razmjerima šteta, na sjednici Gradskoga poglavarstva potom je 11. studenoga 1880. formiran gradski Građevno-eksekutivni odbor u kojem su bili: gradski zastupnik Josip Siebenschein (kao predsjednik), c. kr. nadmjernik Franjo Poppl, kr. nadmjernik Kamilo Bedekovic i gradski potkapetan Franjo Zorac kao izvjestitelj. Odbor je zasjedao u vijecnici, gdje je zaprimao molbe i raspoređivao povjerenstva za uviđaje, a vodio je računa i o osiguravanju potrebnih materijala za radove. ${ }^{32}$ Dan kasnije Vlada je imenovala posebnog povjerenika za grad $\mathrm{Za}$ greb - Maksimilijana (Maksu) Mihalica, koji je trebao zajedno s tadašnjim predstojnikom vladina Građevnog odsjeka Jurjem Augustinom prisustvovati sjednicama kod Gradskoga poglavarstva vezano za mjere koje se odnose na situaciju prouzrokovanu potresom. ${ }^{33}$ Kako bi se u svakome trenutku moglo pomoci stanovnicima, ustanovljena je stalna nocna služba u Gradskoj vijecnici, koja je radila 14 dana, a u njoj su bili gradski potkapetan Franjo Zorac, gradski bilježnik Teodor Mallin i gradski inženjer Milan Lenuci. ${ }^{34}$

Vrlo se brzo pokazalo kako Poglavarstvo ne raspolaže s dovoljno ljudstva da samostalno nadzire i vodi sanaciju grada, jer je tada imalo zaposleno samo dva inženjera, Ruperta Melkusa i Milana Lenucija ${ }^{35}$, pa je Gradska skupština zamolila 12 . studenoga, s jedne strane institucije gradova Graza, Ljubljane, Brežica i Celja da pošalju svoje poduzetnike, a s druge Zemaljsku i Vojnokrajišku vladu za pomoc u tehničkim silama. ${ }^{36}$
Vlada Vojne krajine - iako su i njezine zgrade, kako je spomenuto, iznimno stradale odmah je gradskim vlastima stavila na raspolaganje četiri svoje inženjera: Antuna Seemüllera, Carla pl. Bertelea, Rikarda pl. Rüschera i baruna Camilla Cordona. ${ }^{37}$ A Zemaljska je vlada poslala u pomoc gradu gotovo sve svoje inženjere, kako ce se uostalom vidjeti iz nastavka teksta.

Uz pomoć inženjera koji su raspoređeni, kao i spomenute inženjerske i pionirske satnije kojih je slanje u Zagreb odobrio vladar, organizirano je uklanjanje ruševina i osnovna sanacija građevina. ${ }^{38}$ Građevno-eksekutivni odbor rasporedio je dijelove inženjerske satnije koje je dobio na raspolaganje u sedam odjela na po pet do šest momaka, kojima su bili pridruženi težaci, a koje su isprva vodili vladini i gradski inženjeri Antun Seemüller, Alfred Kappner, Ivan Bartušek, Franjo vitez Ernst, Camillo Cordon, Milan Lenuci i Stjepan (Stevo) Buckl. ${ }^{39}$ Sastav ovih odjela stalno se mijenjao, ovisno o potrebama, a osim navedenih inženjera vodili su ih i Mato Hanžeković, Ivan Szczepaniak i drugi. $4^{\circ}$ Osim za smještaj Gradsko se poglavarstvo pobrinulo i da se svakomu članu inženjerske i pionirske satnije koji je došao u grad

30 HR-HDA-79, UOZV, kut. 396, sv. 10-8, 25047-1880. dok. 25289-1880., Oglas Gradskog poglavarstva, Zagreb, 10. 11. 1880.; ${ }^{\star \star \star}$ 1880.f: 2 ; ${ }^{\star \star \star} 1880$.h: $1-2$

$31 * \star \star$ 1880.12: 1-2

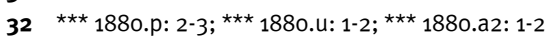

33 HR-HDA-78, PRZV, kut. 121, sv. 6-2483, 1880., dok 2509-1880., PRZV GPZ-u, 12. 11. 1880.

34 *** 1881.e: 4-5

35 Sudeci prema podacima preuzetima iz onodobnih Šematizama javne uprave [VUJASINOVIĆ, 2003-2004: 418-419] $36 * \star *$ 1881.c: $3-4$

37 HR-HDA-79, UOZV, kut. 396, sv. X-8, 25047-1880., dokument 26237-1880., GPZ, ZV-u, Zagreb, 24. 11. 1880.

$38{ }^{\star \star \star}$ 1880.i: 4 ; ${ }^{\star \star *}$ 1881.c: $3-4$

$39{ }^{\star \star \star}$ 1880.k: 1-2; ${ }^{\star \star \star}$ 1880.m: 1-2 
dade „pol litre vina na svakoga momka, da se snaga radina trajnija uzdrži"..$^{41}$

Inženjerske trupe uklonile su brojne ruševne dijelove zgrada, ponajprije dimnjake i oštecene zabate i vijence, pa i cijele zgrade ${ }^{42}$, poput kuce Prister na Trgu bana Jelačica, kuce Pogorelec u Bakačevoj, Sorgač u Petrinjskoj, dijela Medijanskijeve vojarne u Visokoj uli$\mathrm{Ci}^{43}$, dijela franjevačkog samostana prema Opatovini ${ }^{44}$ i drugih zgrada (SI. 13. i 14.). Prema izvještaju Građevno-eksekutivnog odbora Inženjerska satnija radila je na ukupno 135 kuca; učvrstila je 45 zgrada, u potpunosti ili djelomično uklonila 13 građevina, zatim 53 vatrobrana ili zabatna zida i 137 dimnjaka. ${ }^{45}$ Naposljetku su, početkom prosinca, vojnici satnije bili zaposleni i na izgradnji baraka na Ciglani, koje su dopremljene iz Capraga, a u koje se smještala vojska dok se vojarne ponovno ne osposobe za ukonačivanje. ${ }^{46}$

Vojne tehničke čete obavile su golem posao, isticale su se hrabrošcu u uklanjanju oštecenih zgrada ${ }^{47}$, ali ni one nisu bile spremne rušiti objekte „koji su suviše vratolomni i oko kojih bi se morali više tjedana zadržati" ${ }^{48}$, tako da je na rušenju iznimno oštecenoga tornja franjevačke crkve angažiran bečki poduzetnik Oberhauser ${ }^{49}$, dok je uklanjanje vrha tornja katedrale, kao i izvedbu skela unutar ove građevine, izveo Herman Bollé sa svojim radnicima ${ }^{50}$ (Sl. 15.).

Gradski Građevno-eksekutivni odbor nadzirao je i radove koji su kucevlasnici sami izvodili na svojim privatnim kucama, ponajprije kako bi se što prije uklonili njihovi dijelovi koji su bili opasnost za prolaznike, a potom kako bi se obnova provodila po propisima. Postojao je opravdani strah da bi kucevlasnici mogli samo ožbukati oštecene objekte, odnosno kozmetički ih popraviti i potom ih dalje nastaviti iznajmljivati, što bi predstavljalo veliku opasnost za stanare..$^{51}$ Kako bi nadzor bio što efektivniji, grad je bio podijeljen na sedam kotara u kojima su radove nadzirali lokalni inženjeri. Prvi okrug nadzirao je inženjer Franjo Nemec i obuhvacao je ove ulice: Pod zidom, Dolac, Potok, Kožarska, Skalin-

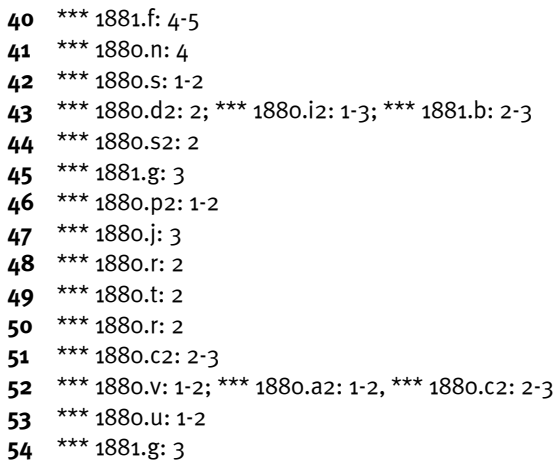

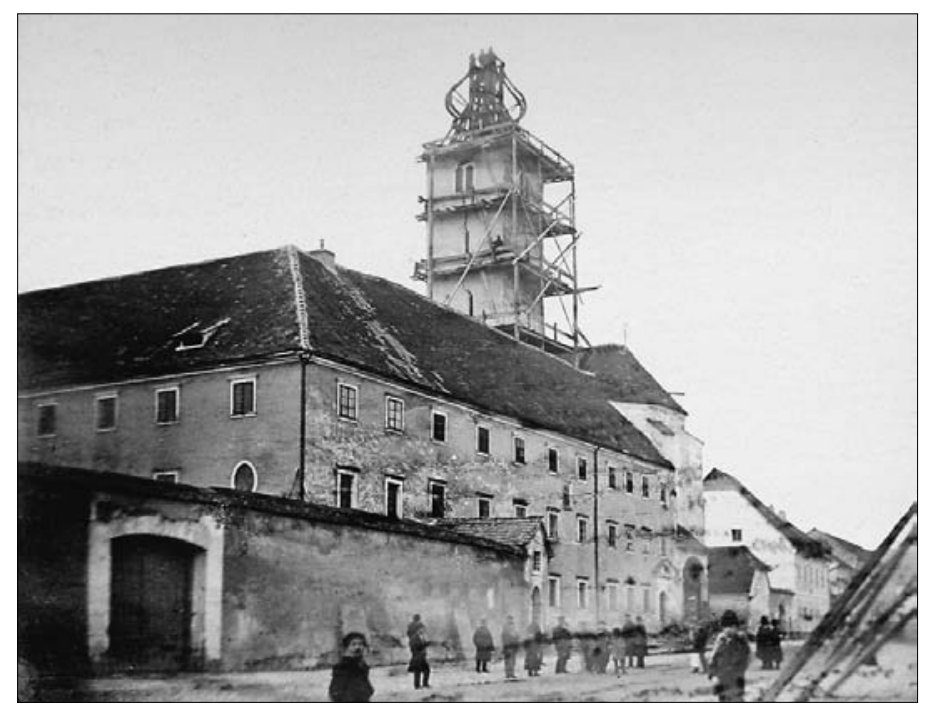

ska, Opatovina, Kaptol, Nova Ves i Bijenička cesta. Drugi je okrug pokrivao inženjer Carl pl. Bertele, a obuhvacao je ove ulice: Potok, Nadbiskupski trg, Vlaška, Draškoviceva, Ružina (danas Kurelčeva), Palmotićeva i Jurišiceva, kao i „povrtnu” (istočnu) stranu Petrinjske. Treći okrug bio je pod nadzorom inženjera Gabriela Dienela i obuhvacao je sve ulice između zapadne strane Petrinjske i Preradoviceve, te Trg bana Jelačica i Zrinjevac. Četvrti okrug nadzirao je inženjer Rikard pl. Rüscher i obuhvacao je llicu od Jelačiceva trga do Frankopanske, potom Frankopansku, Savsku, Sajmišni trg (danas Trg Republike Hrvatske) i sve ulice koje se nalaze između spomenutih ulica i trgova, kao i ulice koje su okomite na Preradovicevu ulicu. Peti okrug nadzirao je inženjer Antun Seemüller i obuhvacao je Ilicu od Frankopanske do Vodovodne, sa svim ulicama koje su južno od toga pravca, zatim Ciglanu, Rokovu ulicu, Radnički dol i Pantovčak. Šesti okrug nadzirao je inženjer Robert Weiß, a obuhvaćao je Mesničku, Bregovitu, Streljačku, Lisinskoga, Demetrovu, Kapucinsku, Sjemenišnu, Vijećničku, Kazališnu i Gospodsku ulicu, te Strossmayerovo šetalište i Grič. Sedmi okrug nadzirao je inženjer Milan Lenuci, a obuhvacao je Dugu, Jurjevsku, Kamenitu i Mletačku ulicu, Trg svetog Marka, te sve ulice koje se nalaze između Potoka, Kožarske ulice, Jezuitskog trga, Trga svete Katarine i Kipnog trga. ${ }^{52}$

Građevno-eksekutivni odbor brinuo se i o nabavi materijala, vapna, pijeska i drva, kao i o raspodjeli radnika koji su stizali u Zagreb. ${ }^{53}$ Tijekom svojega djelovanja nabavio je 540.625 crjepova, 9526 žljebnjaka, 231 nastavaka za dimnjake, 100 komada holandskih vijaka za spone, 16 vagona vapna u težini od $160.000 \mathrm{~kg}$ itd. 54

Dakako, osim nadziranja sanacije privatnih zgrada, uklanjanja jako oštecenih građevina
SL. 15. UKLANJANJE TORNJA FRANJEVAČKE CRKVE u STUDENOME 1880. (FOT. HERMANN FICKERT, 1880.) FIG. 15 REMOVING THE TOWER OF THE FRANCISCAN CHURCH In November, 1880 (PHOto by Hermann Fickert, 1880) 


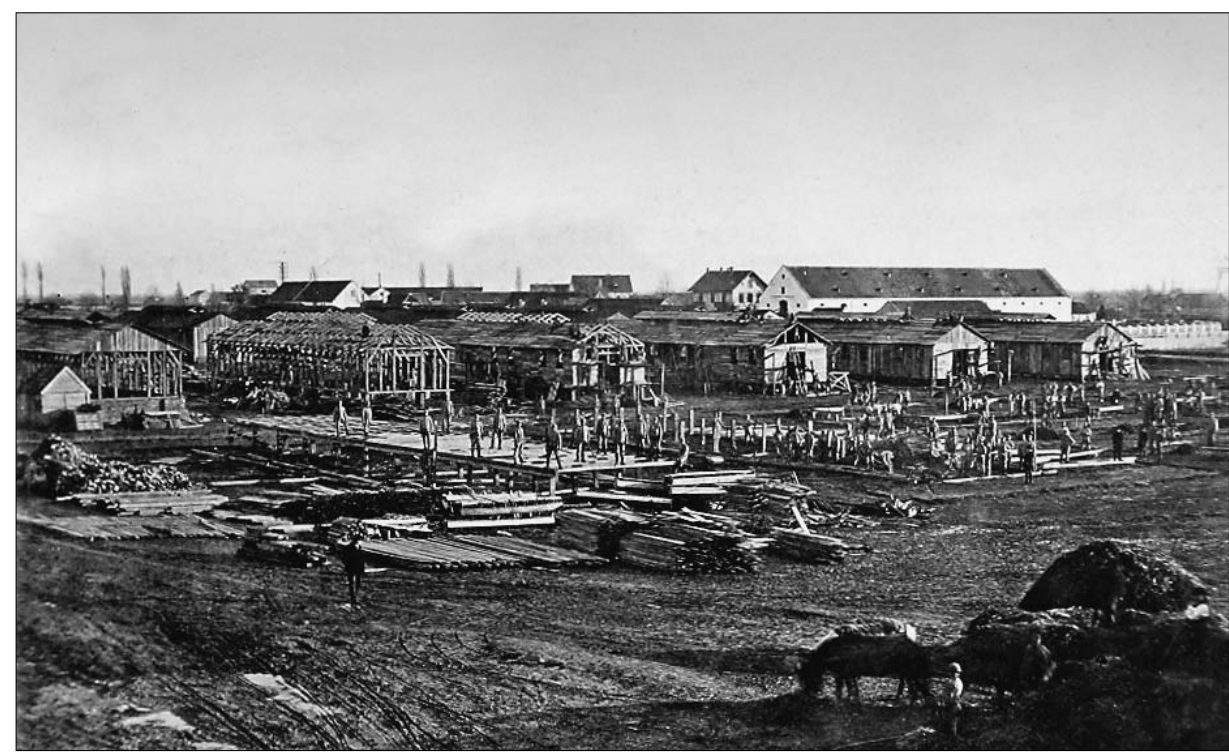

SL. 16. IZGRADNJA VOJNIH BARAKA NA CIGLANI (FOT. HERMANN FICKERT, 1880.)

FIG. 16 BUILDING THE MILITARY BARRACKS IN THE AREA CALled "Ciglana" (PHOTO by HeRMAnN FickeRT 1880) ili njihovih dijelova, Gradsko je poglavarstvo moralo istodobno popravljati zgrade koje su bile u njegovu vlasništvu. Štete na javnim gradskim zgradama procjenjivale su se na oko 45.500 forinti, u što je bio uključen trošak raščišcavanja ulica i izgradnje baraka na Ciglani (Sl. 16.). Sve su gradske javne građevine bile oštecene. Najviše je novca izdano na popravak škola (oko 6000 forinti), gradske ubožnice (oko 4400 for.), crkve svetog Marka (oko 3800 for.), vojarne (oko 2600 for.), Gradske vijecnice (oko 2100 for.), zgrada na Mirogoju (oko 1300 for.) i kule Lotrščak (oko 1250 for.). Na obnovi ovih građevina velikim su dijelom radili privatni poduzetnici Matija Tassoti, Franjo Matiassi, Franjo Pilepic, Gjuro Carnelutti, Ernest Mühlbauer i drugi. ${ }^{55}$

Sva ova brojna navedena imena odnose se, dakako, samo na osoblje koje je rukovodilo poslovima i koje je nadziralo rad brojnih drugih zidara, tesara, limara, krovopokrivača, stolara te drugih majstora i nekvalificiranih radnika. Vrlo brzo nakon potresa iz raznih je dijelova Hrvatske i Europe u Zagreb, naime, došao golem broj majstora i radnika. Samo je iz Ljubljane, navodno, došlo 50 tesara. ${ }^{6}$ Procjene ukupnoga broja radnika koji su došli raditi u Zagreb na popravcima poslije potresa jako variraju u onodobnom tisku. Procjenjivalo se tako da se zidara i tesara skupilo sredinom studenoga gotovo $2000^{57}$, dok je radnika bez nekih posebnih kvalifikacija bilo daleko više. Koliko su te brojke pouzdane, teško je reci. Nesumnjivo je da postoji velika razlika u podacima koji su objavljivani u različitim novinama i onima koji stoje u službenoj evidenciji poglavarstva, a prema kojoj je do 20. studenoga izdano 49 certifikata za domace i strane graditelje koji su htjeli raditi u Zagrebu te 800 radničkih legitimacija. ${ }^{8}$
Kako bi se u što većoj mjeri ubrzao rad na popravcima zgrada, Nadbiskupija zagrebačka odobrila je da se radi i nedjeljom i praznicima nakon što radnici odslušaju jutarnju misu. ${ }^{59}$ Na kolodvoru je bila postavljena knjiga u koju su se mogli upisivati kako kucevlasnici koji su trebali radnike za popravke, tako i radnici koji su dolazili u Zagreb u potrazi za poslom. ${ }^{60}$ Naposljetku se u Zagreb sjatilo toliko radnika da nisu svi ni uspjeli naci posao. ${ }^{61}$

Zahvaljujuci dolasku ovako velikoga broja radnika, do kraja studenoga zgrade su izvana uglavnom bile u osnovnim elementima sanirane, pa se vecinom počelo raditi na uređenju unutrašnjosti. ${ }^{62}$ Dakako, nisu svi bili zadovoljni načinom na koji su obavljeni radovi. Franjo Rački upozorio je oštrog opozicionara - đakovačkog biskupa Josipa Jurja Strossmayera da se nedovoljno kvalitetno obnavlja: „Ovdje se radi na vrat, na nos, ali se samo krpa". ${ }^{63}$ O površnoj i nekvalitetnoj obnovi pisalo se često i u tisku: „U mnogih kucah treba gvozdenih veza, a zidar samo zamaše na oko pukotine". ${ }^{64}$ Bez obzira na kritike, nesumnjivo je da su zgrade bile u dovoljnoj mjeri sanirane da se u njima može proboraviti zima pa se velik dio potresnih „izbjeglica” krajem 1880. vratio u Zagreb.

\section{FINANCIRANJE OBNOVE}

\section{FUNDING THE REHABILITATION AND RECONSTRUCTION PROCESS}

Već prve odredbe Zemaljske vlade o popravcima nakon potresa pokazuju kako se kao ključan problem u sanaciji grada javio nedostatak sredstava. Ban je privremeno odlučio da ce se troškovi podmirivati iz zaklada koje javnim institucijama stoje na raspolaganju, a

55 HR-HDA-78, PRZV, kut. 158, sv. 6-1, 1881., dok 898, GPZ PRZV-u, Zagreb, 24. 2. 1882.
$56 * \star \star$ 1880.j: 2-3
$57 * * *$ 1880.z: 2
$58 * \star \star$ 188o.b2: 2
$59^{\star \star \star}$ 1880.e2: 1-2
$60 * * \star 1880 . j: 2-3$
$61 * \star \star 1880 . f 2: 2$
$62^{\star * \star}$ 1880.m2: 1-2

63 Šıšıć, 1929: 338; Franjo Rački biskupu Strossmayeru, Zagreb, 29. 11. 1880.

$64^{\star * \star}$ 1880.w: 2

65 HR-HDA-79, UOZV, kut. 396, sv. 10-8, 25047-1880., dok. 25407, Ban Ladislav Pejačevic, Naredba svim predstojnikom, nacielnikom, ravnateljem oblastih, sudovah, učilištah, zavodah, itd. Kraljevine Hrvatske i Slavonije, Zagreb, 10. 11. 1880 .

66 TORBAR, 1882: 137

67 Među proračunima koji su otisnuti i dostupni u NSK nije se mogao pronaci primjerak koji se odnosi na 1880 ., stoga se donosi podatak za prvu sljedecu, 1881. godinu, kada je proračun Trojedne Kraljevine iznosio 3603464 for. [*** 1880.a: 1] 
ako ih nema, trebalo se zatražiti od Vlade novac, s time kako je napomenuto da „što vecu štednju pred očima imati valja". ${ }^{5}$

Ukupna šteta nastala potresom bila je procijenjena na 3,275.544 forinti, od čega se na Zagreb odnosilo 2,153.108 forinti. ${ }^{66}$ Kako je u tim godinama proračun Trojedne Kraljevine Hrvatske, Slavonije i Dalmacije tek počeo prelaziti 3,5 milijuna forinti ${ }^{67}$, dok je proračun grada Zagreba u 1880 . godini iznosio 586.453 forinti ${ }^{6}$, hrvatske autonomne i zagrebačke gradske vlasti suočile su se s golemim izazovom: s kojim sredstvima pokriti obnovu Zagreba i okolice?

Štete na građevinama u Zagrebu procjenjivale su se, prema tadašnjoj metodologiji, s obzirom na njihov udio u ukupnim prihodima koje su zgrade godišnje donosile. Najveći dio stambeno-poslovnih građevina u Zagrebu činile su, naime, najamne zgrade, podignute kao investicija pojedinaca, obitelji ili tvrtki, koje su potom donosile prihode od najamnina. Prema procjenama Građevnog odjela Gradskoga poglavarstva u potresu je 845 zgrada u Zagrebu bilo toliko ošteceno da šteta nadmašuje njihov godišnji dohodak, više od 400 bilo je oštećeno preko $40 \%$,nečistoga” (dakle bruto) godišnjega dohotka, dok je procijenjeno da na 400 kuca ima samo manjih šteta. ${ }^{69}$

Uz spomenuti Građevno-eksekutivni odbor, Grad je stoga formirao i odbor za pomoć stradalnicima u potresu, kojemu je predsjedao conte Ivan Buratti, potpredsjednik mu je bio Vatroslav Egersdorfer, a ostali su članovi bili Stjepan Bošnjaković, Albert Schauff i Jakov pl. Weiss kao odbornici te Franjo Gašparić i Andrija Jakčin kao zamjenici. Njima su se sa strane Vlade pridružili Maksimilijan Mihalic i

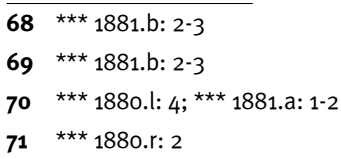
dokument 25508-1880., GPZ Zemaljskoj vladi, Zagreb, 17. 11. 1880.; HR-HDA-79, UOZV, kut. 396, sv. X-8, $25047-$ 1880., dokument 25508-1880., Ban GPZ-u, Zagreb, 17. 11 1880.; ${ }^{\star \star \star} 1880 . \mathrm{y}: 1$

$73 * \star \star$ 1880.q: 3

$74^{\star \star \star} 188$ o.h2: $1-2 ;{ }^{\star \star \star}$ 1880.g2: $1-2$

$75 * \star \star$ 1880.j2: 1

76 HR-HDA-79, UOZV, kut. 684, sv. 10-8, 219-1881., dok. 39797-1883.

$77 * \star \star$ 1880.r2: 2; Zajam je odobren tijekom 1881. HRHDA-79, UOZV, kut. 684, sv. 10-8, 219-1881., dok. 7083, Ministar financija banu, Budimpesta, 13. 3. 1881.

78 HR-HDA-79, UOZV, kut. 684, sv. 10-8, 219-1881., dok. 7083, Ministar financija banu, Budimpešta, 13 3 3. 1881.

79 HR-HDA-79, UOZV, kut. 684, sv. 10-8, 219-1881., dok. 7083, Ban Maksimilijanu Mihalicu, savjetnik Kr. Zem. Vlade, Zagreb, 18. 3. 1881.

80 MihALIC, 1881: 2
Josip Kneisel. ${ }^{70}$ Ban je neposredno nakon potresa dodijelio gradu 20.000 forinti interventnih sredstava, koje je trebalo dijeliti onima koji su najviše stradali. ${ }^{11}$

Kako je blagajna zagrebačkoga Gradskog poglavarstva bila potpuno bez sredstava, tadašnji gradonačelnik Matija Mrazović odlučio je zamoliti bana za dozvolu podizanja zajma od 100.000 forinti za najnužnije radove, dok se u dogledno vrijeme namjeravao podici zajam od čak milijun forinti. Ali ban tu molbu nije odobrio jer je smatrao da zbog potresa Zagreb više nece u nadolazecem vremenu raspolagati s dotadašnjim sredstvima pa nece moći vracati kredite bez podizanja poreza onima koji su najviše stradali u potresu - kucevlasnicima. Tim se neodobravanjem, tumačilo se u banovu dopisu, zapravo štite financijski interesi zagrebačkih građana. ${ }^{72}$ Ban je također odlučio izdavanje potpora građanima Zagreba u potpunosti prenijeti na Unutarnji odjel Zemaljske vlade. Iz zemaljskih zaklada dodijelio je potom 50.000 forinti za povoljne zajmove stradalnicima, a još je 50.000 forinti prispjelo kao beskamatni zajam iz Budimpešte, prema odluci tadašnjega ugarskog ministra predsjednika Istvána Tisze. ${ }^{73}$ Vlada se, konačno, odlučila pobrinuti i za podizanje velikoga zajma.

Ovu je odluku žestoko kritizirao oporbeni tisak, smatrajući kako je riječ o manipulaciji kojom se sve zasluge za obnovu Zagreba žele pripisati Vladi, a osobito se kritiziralo što ce taj posao obavljati Jovan Živković, tadašnji predstojnik Unutrašnjeg odjela Zemaljske vlade. ${ }^{74}$ Konačno, isticalo se da Vlada ima ionako previše posla $s$ obnovom vlastitih stradalih zgrada. ${ }^{75} \mathrm{Ne}$ može se isključiti mogucnost da je ta interpretacija bila točna. Gradom Zagrebom u to je vrijeme, naime, upravljala oporbena Neodvisna narodna stranka. Mora se priznati, međutim, da se banovo upozorenje dijelom obistinilo. Ban je, kako je spomenuto, dodijelio kao nužnu pomoć zagrebačkom poglavarstvu 20.000 forinti, daleko manje od zatraženih 100.000, no i ta ce sredstva grad s velikom teškoćom vracati. ${ }^{76}$

Kako je već napomenuto, brigu o podizanju zajma od milijun forinti preuzela je na sebe Vlada, i ban ga je doista uspio ishoditi od ugarske vlade. ${ }^{77}$ Zajam je odobren četiri mjeseca nakon potresa, sredinom ožujka 1881. godine, na osnovi zakonskog članka IX. Ugarskoga sabora. ${ }^{78}$ Odmah je izabrano i povjerenstvo koje je dijelilo zajmove, kojem je na čelu bio bivši vladin povjerenik za grad Zagreb Maksimilijan Mihalic, koji je nesumnjivo na to mjesto imenovan s obzirom na iskustvo koje je imao radeći nakon potresa u raznim odborima. ${ }^{79}$ Povjerenstvo je počelo raditi krajem travnja $1881 .^{80}$ i djelovalo je do kraja 
1882. godine, a podijelilo je velik dio svote koja mu je stavljena na raspolaganje 962.010 forinti, od kojih 100.000 forinti u vidu beskamatnih kredita, a ostatak kao kredite $s$ kamatama od 4 posto na različite rokove otplate $(15,20$ i 30 godina $) .^{81}$

I tu pomoć opozicija ce, međutim, žestoko napadati. Referentna joj je točka pritom redovito bila pomoć koju je ugarska vlada dodijelila za mađarski grad Segedin nakon poplave 1879. godine. Segedinu je, naime, bilo odobreno čak 8 milijuna forinti povoljnih kredita ili pomoci. ${ }^{82}$ Prepucavanja o tome koliki bi trebao biti iznos pomoci i kredita Hrvatskoj trajat ce mjesecima. Oporba ce neprestano tvrditi da iznos pomoci jasno govori o macehinskom odnosu Budimpešte prema Hrvatskoj ${ }^{83}$, a unionističke hrvatske vlasti veličat ce (pa katkada i preuveličavati) dobivene kredite, a samo ce povremeno zlurado komentirati da bi Hrvatska možda dobila i veće iznose da nije bilo govora neimenovanoga hrvatskog zastupnika u Saboru u Budimpešti, u kojem je istaknuto „da zagrebački potres nije ništa prema udarcu i potresu koji nam dolazi od magjarizacije". ${ }^{84}$

I pozicija i opozicija budno su pratili svaki politički potez, pa i potez perom, vezan za potres i iskorištavali ih za dnevnopolitičke obračune. Opozicijski su listovi napadali isključivo vrh Zemaljske vlade, bana Pejačevica i podbana Živkovica, dok su doprinos u obnovi Zagreba zapovjednika Vojne krajine, baruna Franje Filipovica, ocjenjivali pozitivno. ${ }^{85}$

Budno su se pratili i sadržaji članaka objavljivanih na temu pomoći Zagrebu nakon potresa u tiskovinama prijestolnica, Beča i Budimpešte. Opozicijski je „Obzor” tako javio kako je u „Wiener allgemeine Zeitungu” objavljeno da „Sva Austro-Ugarska nece mirovati, dok se ne podigne novi, ljepši Zagreb!”, dok je s druge strane $u$ „Pester Journalu” potres interpretiran kao kazna Božja Hrvatima, odnosno da „narav često kazni bičem objestne narode, ovakove elementarne nesrece da su opomena takovim bogomrskim narodom. Razorenje Zagreba da je pravedna kazna za podkapanje ugarskoga integriteta". ${ }^{86}$

Konačno, u svim se zagrebačkim dnevnim listovima vrlo detaljno izvještavalo o iznosima koje su razni pojedinci, gradovi, vladari i drugi uglednici darovali za obnovu Zagreba. Ti iznosi nisu bili zanemarivi, a kako se radilo o donacijama, a ne kreditima, odigrali su ključnu ulogu u pomaganju najsiromašnijim slojevima grada Zagreba, iako su i bogatiji građani dobili jedan dio tih sredstava za obnovu svojih domova. Najvecu je potporu dodijelio vladar, Franjo Josip I., koji je u prvim danima nakon potresa donirao 10.000 forinti ${ }^{87}$, da bi početkom 1881. godine, na posebnu molbu biskupa Strossmayera, dodijelio još 2000 forinti za popravak zgrade Jugoslavenske akademije znanosti i umjetnosti. ${ }^{88}$

Spisi predsjedništva Zemaljske vlade otkrivaju da su u pomoć Zagrebu pritekli doista brojni građani gotovo svih dijelova Austro-Ugarske Monarhije, ali i ostatka Europe (dio je novca skupljen cak u Londonu). Ukupno je bilo skupljeno nešto više od 235.000 forinti, što je bio golem iznos za onodobni Zagreb i Hrvatsku. Kako se moglo vidjeti iz prethodnog dijela teksta, riječ je o gotovo $40 \%$ godišnjega proračuna grada Zagreba iz $1880 .{ }^{89}$ i o $7 \%$ iznosa na koji je procijenjena ukupna šteta od potresa.

Osim donacija, beskamatnih kredita i kredita s 4\% kamata, građanima Zagreba nakon potresa država je pokušala pomoći i kroz porezne olakšice. Kucevlasnici su tako dobili oslobođenje od placanja poreza od 3 do 12 mjeseci u postotku ovisnom o stupnju oštecenja zgrada $^{90}$, a ban je uspio ishoditi od Ministarstva financija i to da se oni zagrebački investitori koji se odluče na izgradnju novih zgrada 16 godina oslobode od poreza. ${ }^{91}$

S obzirom na ukupne iznose procijenjenih šteta te na iznose dobivenih potpora i kredita, očito je da su najveći dio troškova obnove ipak snosili građani Zagreba i okolnih mjesta, odnosno u slučaju sakralnih objekata crkvene zajednice. Akumulirani kapital i krediti bankarskih kuća bili su ključni u realizaciji obnove. lako je potres u prvi mah uništio dio ušteđevine bogatijih Zagrepčana, na kraju ce ulaganje u obnovu grada potaknuti razvoj gospodarstva u Zagrebu pa ce godine koje dolaze biti obiljeżene snažnim rastom i razvitkom grada, čime ce većini poduzetnika biti vracena sredstva što su ih uložili u obnovu.

81 HR-HDA-79, UOZV, kut. 684, sv. 10-8, 219-1881., dok 2073-1883, Kneisel banu Pejačevicu, Zagreb, 15. 1. 1883

82 *** 1880.u2:

$83{ }^{\star * \star}$ 1881.j: 1 ; ${ }^{\star \star \star}$ 1881.k: 1

$84^{\star \star \star}$ 1881.l: $1-2$

$85^{\star * \star}$ 1880.k2: 1-2

$86{ }^{\star \star \star}$ 1880.m: $1-2$

$87^{\star \star \star}$ 1880.g: 2

88 HR-HDA-78, PRZV, kut. 157, sv. 6-1, 1881., dok br. 682, PRZV Uredništvu Narodnih novina, Zagreb, 11. 3 1881.

89 HR-HDA-78, PRZV, kut. 158, sv. 6-1, 1881., dok 38341883., Zaključni račun o milodarih za potresom postradale, Zagreb, 17.9.1883.

90 HR-HDA-79, UOZV, kut. 397, sv. X-8, 25047-1880. dokument 29007-1880., Ministarstvo financija Kr. zem. financijskom ravnateljstvu u Zagrebu, Budimpešta, 12. 12. 1880.

$91^{\star * *}$ 1881.h: 2

$92 * * * 1880 . \mathrm{t} 2: 2$

$93^{\star \star \star}$ 1881.g: 3

$94 * \star \star$ 1880.n2: 3; *** 1880.02: 2

$95^{\star \star \star}$ 1881.i: 3 


\section{UMJESTO ZAKLJUČKA}

\section{INSTEAD OF A CONCLUSION}

Usprkos nedostatku sredstava, u samo mjesec dana od potresa završena je nužna obnova gotovo svih javnih zgrada, tako da su sve škole, zavodi i druge javne institucije mogle započeti s radom. ${ }^{22}$ I veliki dio stambenih zgrada saniran je u dovoljnoj mjeri da se mogao koristiti za stanovanje, pa su inženjerijske trupe mogle napustiti grad i vratiti se $u$ Beč još prije Božića $1880 .{ }^{93}$ Predstojali su samo još veliki radovi na obnovi crkava, od kojih ce neki biti završeni vec tijekom 1881. (na crkvi svete Katarine), dok ce na pojedinim građevinama trajati nekoliko desetljeca (na katedrali, franjevačkoj crkvi). Svjesne važnosti normalizacije života za budući razvoj gra$\mathrm{da}$, i gradske su vlasti već početkom prosinca 1880., nepunih mjesec dana nakon potresa, nastavile s izvođenjem radova planiranih otprije, a usmjerenih estetizaciji grada. Tek što su bile raščišcene ruševine s ulica, počelo je tako sađenje drvoreda kestena u Kukovicevoj (danas Hebrangovoj) ulici, a završena je i gradnja stuba i potpornog zida na Vrazovu šetalištu. ${ }^{94} \mathrm{U}$ proljece 1881 . godine potom je uredena cesta prema kolodvoru, prozvana vec tada Prilazom. ${ }^{95}$ Život se vracao u normalu i grad se pripremao za snažan uzlet građevinske djelatnosti koji ce uslijediti već u prvoj godini nakon potresa, da bi se prema kraju 19. stoljeća dodatno ubrzao.

\section{LITERATURA}

BIBLIOGRAPHY
1. BuntaK, F. (1996.), Povijest Zagreba, Nakladni zavod Matice hrvatske, Zagreb

2. BuntaK, F. (1980.), Prije sto godina (1880) zadesio je Zagreb snażan potres, „Kaj”, IV: 25-34, Zagreb

3. Damjanović, D. (2013.), Arhitekt Herman Bollé, Leykam international, Muzej za umjetnost i obrt, Zagreb

4. FICKERT, H. (1880.), Uspomena na zagrebački potres od 9. studenoga 1880. / Erinnerung an das Agramer Erdbeben vom 9. November 1880, Zagreb

5. Hantken von Prudnik, M. (1882.), Das Erdbeben von Agram im Jahre 1880., Bericht an das K. ung. Ministerium für Ackerbau, Industrie und Handel, Budimpešta

6. HoljeVAC, Ž. (2012.), Temelji modernizacije, u: Povijest grada Zagreba. Knjiga 1. Od prethistorije do 1918. [ur. GoldsteIn, I; GoldSTEIN, S.], Novi liber: 298-349, Zagreb

7. Kampuš, I.; KaRAman, I. (1994.), Tisućljetni Zagreb, Školska knjiga, Zagreb

8. Ladović, V.; Premerl, N. (1980.), Potres 1880. i izgradnja Zagreba, Muzej grada Zagreba, Zagreb

9. Minalic, M. (1881.), Für die durch das Erdbeben beschädigten Hausbesitzer, „Agramer Zeitung”, 94 (26.4.): 2, Zagreb

10. StAndL, I. (1881.), Slike zagrebaćkoga potresa od 9. studenoga 1880., Zagreb

11. SzABo, G. (1971.), Stari Zagreb, Spektar, Znanje, Zagreb

12. Šıšıć, F. (1929.), Korespondencija Rački Strossmayer, Knjiga II, JAZU, Zagreb

13. TORBAR, J. (1882.), Izvjeśce o zagrebaćkom potresu 9. studenoga 1880., Djela JAZU, Knjiga I., Zagreb

14. VadAS, A. (2013.), Katasztrófa (történet)? Az 1880. évi zágrábi földrengés példája, „Koral Társadalomtörténeti Folyóirat”, 53: 66-88, Budimpešta

15. Vujasinović, B. (2003.-2004.), Povijesni pregled gradevne slużbe u Hrvatskoj od 1770 . do 1918., „Građevni godišnjak”: 345-562, Zagreb

16. WÄHNER, F. (1883.), Das Erdbeben von Agram am 9. November 1880., Aus dem LXXXVIII. Bande der Sitzungsb. der kais. Akademie der Wiessenschaften, I. Abth., Wien, Aus der kaiserlich - königlichen Hof- und Staatsdruckerei, Bec

17. ${ }^{\star \star \star}$ (1880.a), Proračni Hrvatske i Slavonije, Zagreb

18. ${ }^{\star \star \star}(1880 . b)$, Użasni dani Zagreba: crtice o zagrebačkom potresu sbivšem se 9. studenoga i sljedecih dana god. 1880., Zagreb

19. *** (1880.c), Die Schreckenstage Agrams. Auszüge aus den Berichten der „Agramer Zeitung” über das Erdbeben in Agram vom 9. November und die folgenden Tage, Zagreb

20. *** (1880.d), Slike zagrebackog potresa od 9. studenoga 1880., Album fotografija, Muzej grada Zagreba 


\section{IZVORI}

\section{SOURCES}

21. *** (1880.e), Potres u Zagrebu, „Obzor”, 258 (10.11.): 2, Zagreb

22. $* \star \star ~(1880 . f)$, Potres od 9. studenoga 1880., „Obzor”, 260 (12.11.): 2, Zagreb

23. ${ }^{\star \star \star}(1880 . g)$, Previšnji dar, „Obzor”, 260 (12.11.): 2, Zagreb

24. ${ }^{\star \star \star}(1880 . h)$, Erdbeben, „Agramer Zeitung”, 260 (12.11.): 1-2, Zagreb

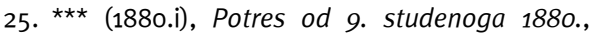
„Obzor”, 261 (13.11.): 3, Zagreb

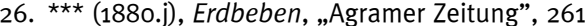
(13.11.): 2-3, Zagreb

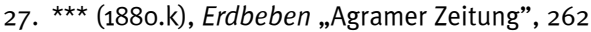
(14.11.): 1-2, Zagreb

28. ${ }^{\star \star \star}$ (1880.l), O potresu, „Narodne novine”, 262 (15.11.): 4, Zagreb

29. ${ }^{\star \star \star}(1880 . \mathrm{m})$, Potres, „Obzor”, 262 (15.11.): 1-2, Zagreb

30. *** (1880.n), Pionirom i żenijskim četam, „Obzor", 262 (15.11.): 4, Zagreb

31. ${ }^{\star \star \star}(1880.0)$, Banska naredba o tehnickoj pripomoci, „Obzor”, 262 (15.11.): 4, Zagreb

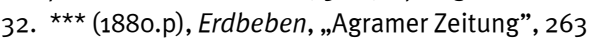
(15.11.): 2-3, Zagreb

33. ${ }^{* \star}(1880 . q)$, Za ublażenje one velike nesrece, „Narodne novine”, 263 (16.11.): 3, Zagreb

34. ${ }^{\star \star \star}$ (1880.r), Potres, „Obzor”, 263 (16.11.): 2, Zagreb

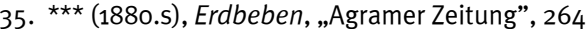
(16.11.): 1-2, Zagreb

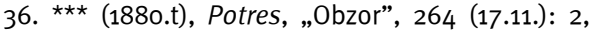
Zagreb

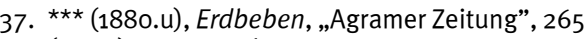
(17.11.): 1-2, Zagreb

38. ${ }^{\star \star \star}(1880 . v)$, Erdbeben, „Agramer Zeitung”, 266 (18.11.): 1-2, Zagreb

39. ${ }^{\star \star \star}$ (1880.w), Potres, „Obzor”, 266 (19.11.): 2, Zagreb

40. ${ }^{\star \star \star}(1880 . x)$, Erdbeben, „Agramer Zeitung”, 267 (19.11.): 2-3, Zagreb

41. $* \star \star ~(1880 . y)$, Banov otpis gradu Zagrebu, „Narodne novine", 267 (20.11.): 1, Zagreb

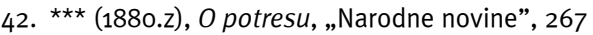
(20.11.): 2, Zagreb

43. ${ }^{* \star \star}(1880 . a 2)$, Poslovanje gradskoga gradjevnoeksekutivnoga odbora, „Obzor”, 267 (20.11.): 1-2, Zagreb

44. ${ }^{\star \star \star}$ (188o.b2), Potres, „Obzor”, 267 (20.11.): 2, Zagreb

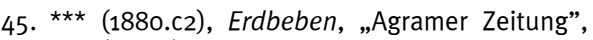
268 (20.11.): 2-3, Zagreb

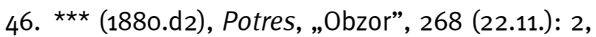
Zagreb

47. *** (1880.e2), Erdbeben, „Agramer Zeitung”, 269 (22.11.): 1-2, Zagreb

48. *** (1880.f2), O potresu, „Narodne novine”, 269 (23.11.): 2, Zagreb

49. ${ }^{\star \star *}$ (1880.g2), Tko da ravna pregradbu Zagreba, „Narodne novine”, 270 (24.11.): 1-2, Zagreb
50. ${ }^{* * *}$ (1880.h2), Preporod grada Zagreba i banske naredbe, I., „Obzor”, 270 (24.11.): 1-2, Zagreb

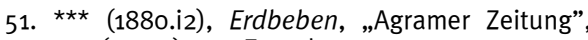
271 (24.11.): 1-3, Zagreb

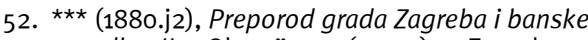
naredbe, II., „Obzor”, 271 (25.11.): 1, Zagreb

53. *** (188o.k2), Potres, „Obzor”, 271 (25.11.): 1-2, Zagreb

54. *** (1880.l2), Erdbeben, „Agramer Zeitung”, 274 (27.11.): 1-2, Zagreb

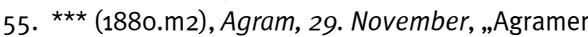
Zeitung”, 275 (29.11.): 1-2, Zagreb

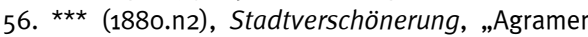
Zeitung", 280 (4.12.): 3, Zagreb

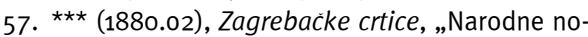
vine", 280 (6.12.): 2, Zagreb

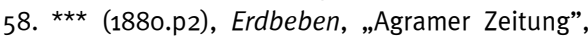
281 (6.12.): 1-2, Zagreb

59. ${ }^{\star \star \star}$ (1880.r2), Zajam od 1 milijuna, „Obzor”, 282 (9.12.): 2, Zagreb

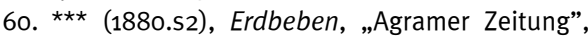
284 (10.12.): 2, Zagreb

61. ${ }^{\star \star \star}$ (1880.t2), Zagrebacke crtice, „Narodne novine", 284 (11.12.): 2, Zagreb

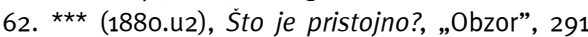
(20.12.): 1, Zagreb

63. ${ }^{* \star \star}$ (1881.a), Die Thätigkeit des Comités zur Unterstützung der durch das Erdbeben verunglückten Bewohner Agrams, „Agramer Zeitung”, 16 (21.1.): 1-2, Zagreb

64. *** (1881.b), Gradsko zastupstvo zagrebacko, „Narodne novine”, 42 (22.2.): 2-3, Zagreb

65. ${ }^{\star \star \star}$ (1881.c), Izvjeśce gradjevno-eksekutivnoga odbora u Zagrebu podneseno gradskomu za stupstvu u sjednici od 21. veljace o.g., I., „Narodne novine", 45 (25.2.): 3-4, Zagreb

66. *** (1881.d), Izvieśce gradskoga načelnika o djelovanju zastupstva i poglavarstva sl. $\mathrm{kr}$. Gl. Grada Zagreba u g. 1880., „Obzor”, 45 (25.2.): 2-6, Zagreb

67. ${ }^{\star * \star}$ (1881.e), Izvješce gradjevno-eksekutivnoga odbora u Zagrebu podnešeno gradskomu zastupstvu u sjednici od 21. veljace o.g., II., „Narodne novine", 46 (26.2.): 4-5, Zagreb

68. ${ }^{* \star *}$ (1881.f), Izvjesce gradjevno-eksekutivnoga odbora u Zagrebu podneseno gradskomu zastupstvu u sjednici od 21. veljace o. g., III., „Narodne novine", 47 (28.2.): 4-5, Zagreb

69. ${ }^{\star \star \star}(1881 . g)$, Izvješce gradjevno-eksekutivnoga odbora u Zagrebu podnešeno gradskomu za stupstvu u sjednici od 21. veljače o.g., IV., „Narodne novine", 48 (1.3.): 3, Zagreb

70. $* \star \star ~(1881 . h), O$ gradnjah na Jelačicevu trgu, „Narodne novine", 49 (2.3.): 2, Zagreb

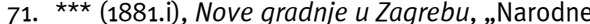
novine", 54 (8.3.): 3, Zagreb

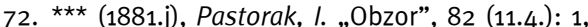
Zagreb

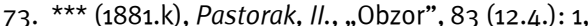
Zagreb

74. ${ }^{\star \star \star}(1881 . l)$, Zagreb - Segedin, „Narodne novine”, 88 (19.4.): 1-2, Zagreb

\section{ARHIVSKI IZVORI}

\section{ARCHIVE SOURCES}

1. Hrvatski državni arhiv, fond br. 78 , Predsjedništvo Zemaljske vlade [HR-HDA-78, PRZV]

2. Hrvatski državni arhiv, fond br. 79 , Unutrašnji odsjek Zemaljske vlade [HR-HDA-79, UOZV]

IZVORI ILUSTRACIJA

\section{ILLUSTRATION SOURCES}

SL. 1., 3.,

8., 11., 13. STANDL, 1881.

SL. 2. HANTKEN VON PRUdNIK, 1882: pl. XI.

SL. $4 ., 7$.

9., 10. FICKERT, 1880.; Muzej grada Zagreba [dalje MGZ]

SL. 5. $\quad \star \star \star ~ 1880 . d: 30$, MGZ

SL. 6. „Leipziger illustrirte Zeitung”, 75/1953 (4.12.1880.): 478

SL. 12. HANTKEN VON PRUdNIK, 1882: Taf. IX

SL. 14. Ministarstvo kulture Republike Hrvatske [MKRH] inv. br.: 994; neg.: /

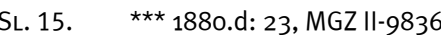

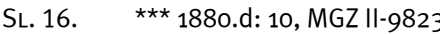




\title{
SAŽETAK
}

\author{
SUMMARY
}

\section{ORganization OF REPAIR AND RECONSTRUCTION WORKS IN ZagREB AFTER THE 1880 EARTHQUAKE}

The earthquake that hit Zagreb on November 9, 1880 , with a magnitude of $6.1-6.3$ on the Richter scale, was one of the greatest natural disasters that has ever hit this city throughout its history. It profoundly affected its architecture and urban de velopment. The aim of this paper is to show how the Croatian governmental bodies organized the repair, reconstruction, and renovation of the build ings in Zagreb immediately after the earthquake in November and December 1880 and who was actually put in charge of the entire process and control of the works. It also examines the issue of financial and other constraints at the time. This analysis is based on the documents from the archives of the central bodies of the Triune Kingdom of Croatia, Slavonia and Dalmatia (Presidency and the Department for Internal Affairs of the Croatian Provincial Government) as well as the newspapers of the period such as the pro-government Narodne novine and Agramer Zeitung and the oppositional one called Obzor. The reconstruction and repair of the city and its surroundings was supervised by the Building Section of the Department for Internal Affairs of the Croatian Provincial Government. However, numerous other institutions were engaged in the process as well, in the first place the City Council of Zagreb headed by the mayor Matija Mrazovic (and his Building Department), the Zagreb County and the government of Military Frontier (Vojna Krajina) still in existence at the time headed by the general baron Franjo Filipovic. Despite the fact that the system of public services in Zagreb was quite complex due to a large number of civil engineers employed in various institutions and despite the presence of many architects, builders and other craftsmen, there were not enough professionals nor workers who could effectively cover the full scope of the damage. Soon after the earthquake, the central institutions from Vienna offered help, in the first place the Ministry of War, one of the very few ministries in charge of the entire territory of the Monarchy following the 1867 Austro-Hungarian Compromise. As a result two companies (the Engineering and the Pioneer one) arrived in Zagreb on November 12 . The reconstruction and repair of public buildings was led by the public institutions. The renovation of residential and office buildings, i.e. private buildings, was mostly led by the owners themselves, although the whole process was su- pervised by the city authorities. After getting an insight into the extent of the damage immediately after the earthquake, the City Council approved the constitution of the Building and Executive Committee during its session on November, 11, 1880. Josip Siebenschein, the city representative, was appointed head of the newly-formed committee. The Committee held its sessions in the city hall where it received requests and established the investigative commissions. It also took care of providing the building material. Besides the above mentioned Building and Executive Committee, the City Government formed a committee to assist the victims of the earthquake, which was chaired by Ivan Buratti. Furthermore, the day after the earthquake, the City Government issued a provision on the restrictions regarding the prices of construction materials and construction works in order to assist the homeowners whose buildings were damaged and to prevent any potential speculative activity following the earthquake. The very first provisions issued by the Croatian Provincial Government on postearthquake repairs clearly indicated that the central problem appeared to be lack of funds. Consequently, the Ban decided to cover reconstruction and repair costs from the foundations that were at the disposal of public institutions with a remark that "care should be taken to use the available funds in the most economical way possible." The total damage caused by the earthquake was estimated at 3,275,544 forints, of which 2,153,108 was related to the damages in the City of Zagreb. In view of the fact that the budget of the Triune Kingdom of Croatia, Slavonia and Dalmatia was slightly over 3.5 million forints and the budget for the City Government of Zagreb in 1880 amounted to 586,453 forints, the Croatian autonomous and local Zagreb city authorities were faced with an enormous challenge as to which funds could be used for the reconstruction and repair of the buildings in Zagreb and its surroundings. The extent of the building damage in Zagreb was estimated by the methodology of the period, given its share in the income that the buildings generated annually. The majority of residential and office buildings in $\mathrm{Za}$ greb were in fact rental buildings. They were usually considered as a form of individual, family or company investment with expected return and profit. According to the estimates made by the Con- struction Department of the City Government, 845 earthquake-hit buildings in Zagreb were so badly damaged that the damage actually exceeded their annual income, the damage on over 400 buildings exceeded $40 \%$ of gross annual income, and finally 400 houses suffered only minor damage. The reconstruction and repair of Zagreb was financially supported both by the Provincial Government and the Hungarian Government in Budapest. The Ban allocated 50000 forints through interest-free loans from the Croatian independent funding sources and an equal amount was granted by the Hungarian Prime Minister István Tisza. Furthermore, four months after the earthquake, in mid-March 1881, the Hungarian Parliament allocated a million forint loan on the basis of the Article IX of the Law. Of this amount 100,000 forints were granted in the form of interest-free loans while the rest were loans with interest rates of $4 \%$ on various repayment terms $(15,20$ and 30 years). The presidential documents of the Provincial Government reveal that the post-earthquake repair and renovation process was financially supported by many citizens from almost all parts of the Austro-Hungarian Monarchy as well as from the rest of Europe. As a result, over 235,000 forints was collected. This huge amount of money at the time accounted for almost $40 \%$ of the annual budget of the Zagreb city in 1880 and $7 \%$ of the total estimate of the earthquake damage. In addition to donations and loans to the citizens of Zagreb, the state also provided help through tax relief scheme. Homeowners were granted a tax-exempt status from 3 to 12 months in percentage relative to the extent of the estimated building damage. Tax-exempt status for a period of 16 years was also granted to those who decided to build new buildings. Reconstruction and repair works on almost all public buildings were completed within just one month after the earthquake so that all schools, institutes and other public institutions could resume work. A large number of residential buildings were sufficiently repaired and renovated to be habitable again. The renovation of the churches still lay ahead, however. Major repair works were undertaken subsequently of which some were completed as early as 1881 (Church of St. Catherine) while the restoration of some structures lasted for decades (the Cathedral and Church of St. Francis).
BIOGRAFIJA

\section{BIOGRAPHY}

Dr.sc. DRAGAn Damjanović rođen je 1978. godine u Osijeku. Redoviti je profesor na Odsjeku za povijest umjetnosti Filozofskog fakulteta Sveučilišta u Zagrebu, na kojem radi od 2003. godine. Glavni mu je interes vezan za povijest hrvatske arhitekture 19. i 20. stoljeca. Voditelj je projekta Hrvatske zaklade za znanost „Umjetnost i država u Hrvatskoj od prosvjetiteljstva do danas” (od 2018. godine).
Dragan Damjanović, Ph.D., born in 1978, Full Professor in the Department of Art History at the Faculty of Humanities and Social Sciences in Zagreb since 2003. His main research interests are focused on the history of Croatian architecture in the $19^{\text {th }}$ and $2 \mathrm{O}^{\text {th }} \mathrm{C}$. He currently runs the project "Art and the State in Croatia from the Enlightenment to the Present" funded by the Croatian Science Foundation (from 2018). 
